\title{
Barnacles (Cirripedia: Thoracica) of the Dampier Archipelago, Western Australia
}

\author{
Diana S. Jones \\ Department of Aquatic Zoology (Crustacea), Western Australian Museum, \\ Francis Street, Perth, Western Australia 6000, Australia \\ email: diana.jones@museum.wa.gov.au
}

\begin{abstract}
Thirty-five species of littoral and shallow-water bamacle species were collected during the expeditions and fieldwork in the tropical waters of the Dampier Archipelago. Barnacle communities stratify on the basis of depth, with intertidal, shallow subtidal and deeper subtidal communities recognisable. Clear distribution differences exist between intertidal and deeper water communities; the shallower water subtidal community is somewhat intermediate, with some species wide-ranging. Species diversity is greatest in the intertidal whereas many of the deeper water stations are dominated by only one or two species. A checklist produced from barnacle records contained in the collections of Australian museums presently documents 49 littoral and shallow-water barnacle species from the Dampier Archipelago. The fauna is dominated by species with Indo-West Pacific and Indo-Australian distributions. It shows strong affinities with that of the Kimberley area to the north and many similarities with those of the more southern Muiron Islands, Exmouth Gulf and Montebello Islands in northern Western Australia. The fauna, however, differs significantly from the barnacle fauna of the southern Australian warm temperate province. First collections of Balanus reticulatus and Megabalanus rosa raise the number of introduced barnacle species currently recorded from the Dampier Archipelago to six.
\end{abstract}

\section{INTRODUCTION}

Prior to the 1990 's, the barnacle fauna of northwestern Australia had been detailed only briefly. First collections were by the German Gazelle Expedition (1874-76), which collected barnacles, corals and echinoderms at the Dampier Archipelago (Meermaidstreet) and Shark Bay (Weltner, 1897). Barnacles epizoic on turtles and sea snakes in northwestem Australian waters were recorded by Krüger (1911) and Nilsson-Cantell (1921), respectively. The Mjöberg Swedish Scientific Expedition of 1910-1913 to northwestern Australia (Cape Jaubert area) recorded 10 barnacle species (Broch, 1916), of which six showed Malayan affinities and four were new, commensal with gorgonians, sponges and antipatharians. Reporting on barnacles collected by Dr Th. Mortensen's Pacific Expedition (1914-1916) in the Pacific Ocean, Broch (1922) also demonstrated a faunistic relationship between some Australian cirripede species and those of the Malaysian region. Hiro (1936), describing new barnacle species collected from north of Darwin at the shoal Zyumonzi-syô $\left(11^{\circ} 00^{\prime} \mathrm{S}, 130^{\circ} 00^{\prime} \mathrm{E}\right)$, commented on the paucity of knowledge of the cirripede fauna in northern and western areas of Australia and suggested that Zyûmonzi-syô and northwestern Australia (Cape
Jaubert) were similar, both biogeographically and topographically.

Not until 1990 were the shallow-and deep-water barnacle faunas of Australia documented for the first time (Jones et al., 1990). From museum collection holdings and literature records, these authors identified 41 neustonic and shallower water (to $200 \mathrm{~m}$ ) and 7 deeper water $\left(200^{+} \mathrm{m}\right.$ ) cirripede species as occurring along the coast of northwestern Australian.

Systematic collecting of the northwestern Australian barnacle fauna began in 1989 , at the Buccaneer Archipelago (16 $\left.11^{\prime} \mathrm{S}, 123^{\circ} 24^{\prime} \mathrm{E}\right)$ in the Kimberley area, during a short WA Museum/WA Fisheries sampling cruise aboard the research vessel Flinders, followed by the WA Museum Kimberley Islands and Reefs Expedition (KIRE) in 1991. A detailed report of the KIRE barnacles documented 54 species (Jones, 1992a). Two additional species were later added (Jones and Hewitt, 1997), making a total of 56 for the Kimberley area. Further WA Museum expeditionary work in tropical northwestern Australian has been conducted to the south of the Kimberley, around the area of North West Cape $\left(21^{\circ} 47^{\prime} \mathrm{S}, 114^{\circ} 10^{\prime} \mathrm{E}\right)$. Thirty-nine species of shallow water and neustonic cirripede species have been recorded from the Muiron Islands and 
the eastern shores of Exmouth Gulf (Jones and Hewitt, 1996). Further collecting at the Montebello Islands added an additional five species, making a total of 44 from the North West Cape area (Jones and Berry, 2000).

Prior to the Woodside Energy Ltd/Western Australia Museum partnership fieldwork in the Dampier Archipelago, a small number of barnacles had been collected between 1972-1974 during WA Museum expeditions to Kendrew Island and nearby reefs and to Enderby Island (1987), when the western side of the Burrup Peninsula and some offshore islands were also visited.

The present report examines the large collection of shallow-water barnacles amassed from the 19982001 Woodside Energy Ltd/Western Australia Museum partnership. This four-year survey involved a workshop and one dredging and two diving expeditions in the archipelago, as well as numerous surveys along shores of the Burrup Peninsula and the adjacent mainland. These records have been amalgamated with those of cirripedes from the Dampier Archipelago collected by previous WA Museum expeditions, as well as cirripedes contained in other Australian Museum collections, to produce a checklist of the littoral and shallow-water barnacle species of the waters of the Dampier Archipelago.

\section{MATERIALS AND METHODS}

Specimens were collected at low tide by hand from a wide variety of habitats (e.g. rocks, reefs, mangroves). Subtidal samples were collected by SCUBA or by dredging. Dredged samples were obtained using a box-shaped dredge measuring $1200 \mathrm{~cm} \times 330 \mathrm{~cm}$ at the mouth with a $1 \mathrm{~cm}$ mesh. All dredge runs were at a vessel speed of 2-3 knots and of 10 minutes duration.

Emphasis was placed particularly on collecting cryptic barnacle species and those epizoic on or commensal in a variety of hosts (e.g. decapod crustaceans, sponges, corals, gorgonians). Where possible, barnacles epizoic on marine reptiles and mammals were sampled. Collections are deposited in the collection of the Crustacean Department at the Western Australian Museum, Perth.

Cirripedes contained in the collections of the Western Australian Museum were reviewed for records from the Dampier Archipelago, along with collections from a number of other Australian museums - i.e. the Australian Museum (Sydney, New South Wales), the Melbourne Museum (Melbourne, Victoria), the Museum and Art Gallery of the Northern Territory (Darwin, Northern Territory), the Queensland Museum (Brisbane, Queensland) and the South Australian Museum (Adelaide, South Australia).

The general arrangement of taxa follows Newman
(1996). Genera are listed alphabetically within families and species alphabetically within genera. Abbreviations are as follows: WAM $C=$ Western Australian Museum Crustacean Collection; AM P = Australian Museum Crustacean Collection.

\section{RESULTS}

The sampling stations and barnacle species collected during the two diving expeditions (DA1, DA3), the dredging expedition (DA2), the workshop and additional shore collecting along the Burrup Peninsula and the adjacent mainland are listed (Appendix 1). Thirty-five barnacle species were collected.

\section{Additional intertidal shore collections}

Shore collecting provided 19 barnacle species (Tables 1 and 2). The site with the highest barnacle diversity was Watering Cove on the east side of the Burrup Peninsula (17 species). This number may, however, be partly a result of increased sampling effort at this locality. Other sites with high diversities were Point Cleaverville (9 species) and Withnell Bay and Dampier Beach (each with 8 species). The least diverse mainland station was at Dampier Salt Ltd. Beach (three species), an area that has been subjected to anthropogenic influences.

Balanus amphitrite Darwin, 1854 and B. cirratus Darwin, 1854 were the most widely distributed species (at six sites) (Table 3 ). The majority of species occurring at only one site were epizoic Octolasmis cf. bullata (Aurivillius, 1892) attached to the gills of Portunus pelagicus (Linnaeus, 1758); Chelonibia cf. caretta (Spengler, 1790) attached to the carapace of Eretmochelys imbricata (Borradaile); Armatobalanus quadrivittatus (Darwin, 1854) attached to Acanthopleura spinosa (Bruguière, 1792); and Acasta spp attached to intertidal sponges.

\section{Diving expeditions (DA1/98, DA3/99)}

The two diving expeditions DA1/98 and DA3/99 included sampling at intertidal as well as diving stations. Twenty barnacle species were collected (11 intertidal and nine subtidal species). Barnacles were collected at $27(77 \%)$ of the DA1/98 stations and at $21(61 \%)$ of the DA3/99 stations. Nineteen and 18 barnacle species were collected by these respective expeditions (Tables 4 and 5). Seventeen species were common to both the DA1/98 and DA3/99. Fourteen species collected by the diving expeditions (DA1/98 and DA3/99) were not collected during the dredging expedition (DA2/99). Two subtidal species were collected only by the DA1/98 expedition, Armatobalanus cf. cepa (Darwin, 1854) and Striatobalanus tenuis (Hoek, 1883). The former was only collected during DA1/98; the latter was 


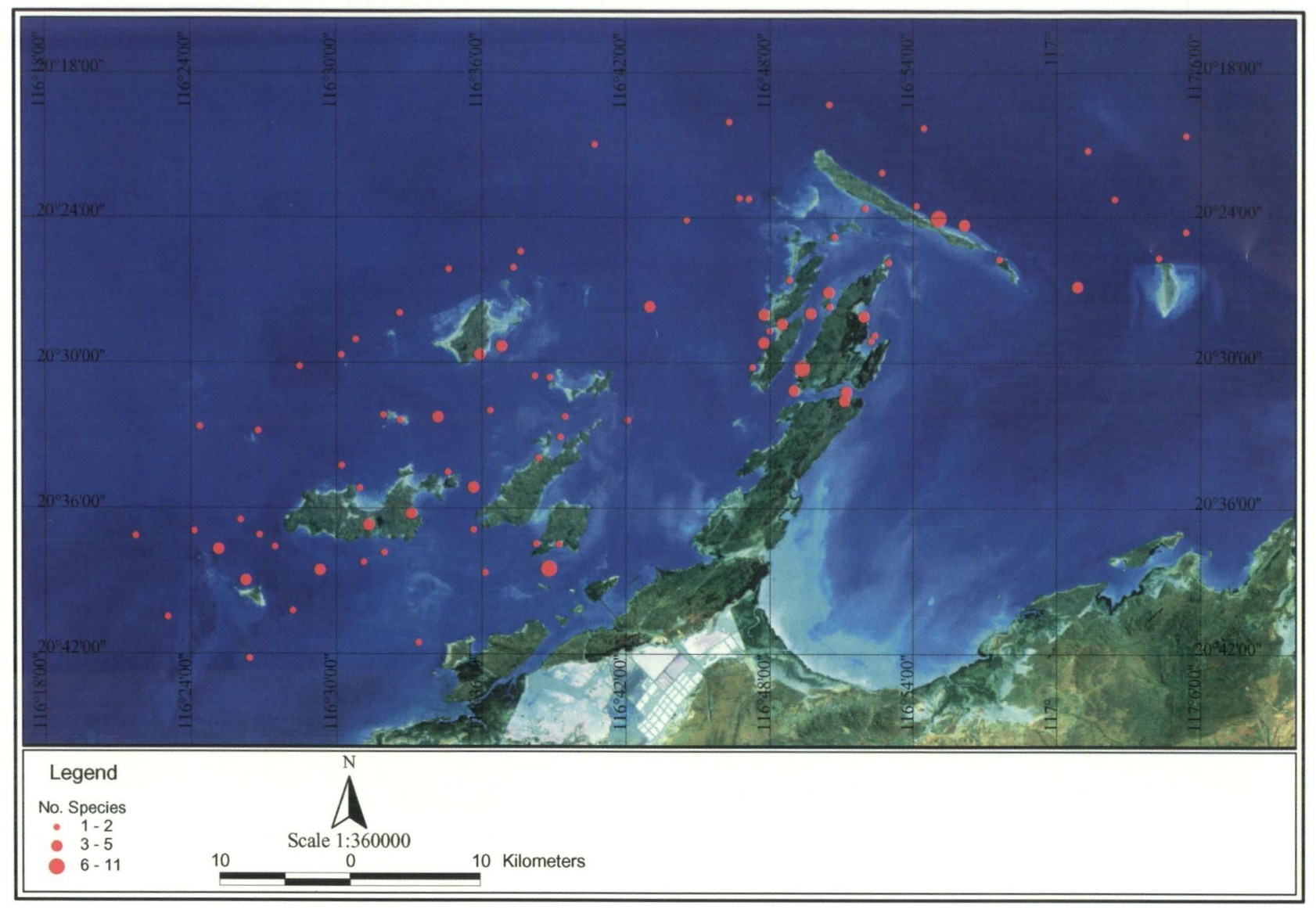

Figure 1 Numbers of barnacle species collected by diving (DA1/98 and DA3/99) and dredging (DA2/99) expeditions.

also collected by the dredging expedition (DA2/99). The intertidal pedunculate Lithotrya valentiana (Gray, 1825) was collected only by the DA3/99 expedition (Table 6).

\section{Intertidal stations: DA1/98 and DA3/99}

The site with the highest barnacle diversity was DA1/98/11 at Dolphin Island, in the northeast of the archipelago (seven species) (Figure 1 and Table 2 ). Seven sites with moderate diversities had between three to five species present. Sites ranged from the northeast of the archipelago (three sites) to the outer northwestern edge of the archipelago (two sites) and, closer to the mainland, the southwestern archipelago (two sites). The least diverse intertidal stations had one or two barnacle species present (four stations in the northeast and five in the inner islands of the archipelago).

\section{Subtidal stations: DA1/98 and DA3/99}

\section{0-10 m depth}

The highest diversity was at DA1/98/27 (1.0-8.0 $\mathrm{m}$, Legendre Island) with 11 species However, eight of these are intertidal and three are subtidal species (Table 7). Excluding intertidal species, stations in the northeast of the archipelago showed the greatest diversity. Station DA1/98/33 (Angel Island) was the most diverse subtidal station (five species) followed by a Burrup Peninsula site (DA1/98/30) with four species and three at Legendre Island (DA1/98/27) and Angel Island (DA1/98/08) (Figure 1 and Table 7 ).

The lowest diversity was at subtidal stations where only one (six stations) or two species (five stations) were obtained. Four of the five stations with two species were in the northeast and one station was in the northwest of the archipelago. Three of the six stations with one species were in the northeast and three in the inner islands of the archipelago (Figure 1 and Table 7).

\section{1-20 $m$ depth}

The highest diversity at this depth range was in the inner islands of the archipelago, in a channel between Enderby and West Lewis Islands, with five species (DA3/99/55). Three species were collected from three stations and two from three stations. Of these, three stations were in the southwest and three in the northeast of the archipelago. The least diverse stations (three with one species each) occurred either along the outer edge (DA1/98/32 Legendre Island) or toward the extreme western (DA1/98/50 Bare Rock) or extreme eastern (DA1/ 98/21 Delambre Island) extent of the Dampier Archipelago (Figure 1 and Table 7). 


\section{$21 \rightarrow 30 \mathrm{~m}$ depth}

Three stations were sampled over this depth range along the outer edge of the archipelago. Two species were sampled from DA3/99/39 (Brigadier Island) and one species was collected from stations DA1/98/26 (Madeleine Shoals) and DA3/98/52 (Roly Rock) (Figure 1 and Table 7 ).

\section{Species distribution}

\section{Intertidal species}

The most widely distributed intertidal species collected by the DA1/98 and DA3/99 expeditions were Tetraclitella sp. nov., Tetraclita squamosa (Bruguière, 1789), Balanus reticulatus Utinomi, 1967 and Megabalanus tintinnabulum (Linnaeus, 1758), collected from nine stations. Three species Chthamalus malayensis Pilsbry, 1916, Caudoeuraphia cf. caudata (Pilsbry, 1916) and Newmanella vitiata (Darwin, 1854) - were each collected from seven stations. Balanus sp. nov. occurred at six stations and Ibla cumingi Darwin, 1851 at five. Balanus amphitrite Darwin, 1854 occurred intertidally at four and $B$. cirratus Darwin, 1854 at three stations. Lithotrya valentiana (Gray, 1825) was collected from one station only (Table 8).

\section{Subtidal species}

(Note: intertidal species that extend into shallower water are included in this category)

Acasta spp associated with sponges were the most widely distributed subtidal barnacles, being collected from $17(24 \%)$ of the 70 dive stations sampled (from the intertidal to a depth of $19 \mathrm{~m}$ ). These were followed by the coral commensals, pyrgomatid spp, collected from depths of $0-27 \mathrm{~m}$ from 11 stations (16\%). Conopea spp associated with gorgonians were collected from nine stations (13\%), from the intertidal to $30 \mathrm{~m}$ depth. Striatobalanus amaryllis (Darwin, 1854) occurred at five stations $(7 \%)$, from the intertidal to $17 \mathrm{~m}$. Armatobalanus cf. cepa (Darwin, 1854), A. quadrivittatus (Darwin, 1854) and Megabalanus rosa Pilsbry, 1916, each occurred at three stations (intertidal to $10 \mathrm{~m}, 1-20 \mathrm{~m}$, and intertidal to $8 \mathrm{~m}$, respectively) and Striatobalanus tenuis (Hoek, 1883) was collected from one (at depths of 1-10 m) (Table 9).

\section{Dredging expedition (DA2/99)}

A total of 14 subtidal barnacle species was collected from 41 of the 100 DA2/99 dredging expedition stations (Table 10).

\section{o-10 $\mathrm{m}$ depth}

Species diversity at this depth was low. Three species were collected from one station in the northeast (DA2/99/62 Flying Foam Passage) and one species was obtained from four stations which were all in the inner southwestern areas of the archipelago (Figure 1 and Table 11).

\section{$11-20 \mathrm{~m}$ depth}

The highest diversity at this depth range was in the inner islands (DA2/99/65 off Intercourse Island with seven species; DA2/99/33 Malus Islands, five species; DA2/99/75 Goodwyn Island, four species; and DA2/99/74 SE Enderby Island, three species) and in the northeast (DA2/99/13 off Haüy Island with five species) of the archipelago. Lowest diversity (one or two species) occurred at stations scattered throughout the archipelago, with two species from 13 stations and one from each of 22 stations (Figure 1 and Table 11).

\section{$21->30 \mathrm{~m}$ depth}

Species diversity at this depth was also low. Of the sixteen stations sampled, and which were scattered throughout the archipelago, two species were collected from six stations and one other from the remainder (Figure 1 and Table 11).

\section{Species distribution}

Striatobalanus amaryllis (Darwin, 1854) was the most widely distributed species, being collected between depths of 7.0-38.5 $\mathrm{m}$ from $31(47 \%)$ stations. Conopea calceolus (Ellis, 1758) and Acasta spp were each collected from $11(16 \%)$ stations (depths $10.0-38.0 \mathrm{~m}$ and $9.0-38.5 \mathrm{~m}$, respectively) and Conopea spp were collected between depths of $7.0-43.0 \mathrm{~m}$ from eight (11\%) stations (Table 12 ).

The remaining 10 species were collected from appreciably fewer stations. Solidobalanus ciliatus (Hoek, 1913) was collected from three (12.5-19.5 m) and Armatobalanus terebratus (Darwin, 1854) and pyrgomatid spp each from two stations $(7.0-15.0 \mathrm{~m}$ and $18.0-21.0 \mathrm{~m}$, respectively). Seven species (Calantica sp. nov., Armatobalanus arcuatus Hoek, 1913, A. quadrivittatus Hoek, 1913, Striatobalanus bimae (Hoek, 1913), S. tenuis (Hoek, 1883), Conopea sp. 1 cf. navicula (Darwin, 1854) and Conopea sp. 2 cf. dentifer (Broch, 1922) were each collected from one station, from depths of $19.5 \mathrm{~m}, 32.0-33.0 \mathrm{~m}$, $38.0 \mathrm{~m}, 18.0-21.0 \mathrm{~m}, 38.5 \mathrm{~m}, 10.0-15.0 \mathrm{~m}$ and 10.0 $15.0 \mathrm{~m}$, respectively.

\section{Comparison between the diving (DA1/98, DA3/99) and dredging (DA2/99) expeditions}

A total of 28 barnacle species was collected by the diving and the dredging expeditions. Of these, 12 are intertidal species, 11 of which were also collected from stations included in the diving expeditions (DA1/98 and DA3/99). The intertidal pedunculate Lithotrya valentiana (Gray, 1825) was collected exclusively by DA3/99 (from an intertidal station). Five species/taxa (Armatobalanus quadrivittatus (Darwin, 1854), Striatobalanus amaryllis 
(Darwin, 1854), Conopea spp, Acasta spp, pyrgomatid spp) were common to all the expeditions (Table 6). Two species, Megabalanus rosa (Pilsbry, 1916) and $M$. tintinnabulum (Linnaeus, 1758), were collected only by the diving expeditions. The subtidal Striatobalanus tenuis (Hoek, 1883) was collected by the diving expedition DA1/98 as well as by the dredging expedition DA2/99. Eight subtidal species were collected exclusively by the dredging expedition DA2/99 Calantica sp. nov., Armatobalanus arcuatus Hoek, 1913, A. terebratus (Darwin, 1854), Solidobalanus ciliatus (Hoek, 1913), Striatobalanus bimae Hoek, 1913, Conopea calceolus (Ellis, 1758), Conopea sp. 1 cf. navicula (Darwin, 1854) and Conopea sp. 2 cf. dentifer (Broch, 1922) and DA1/98 exclusively collected Armatobalanus cf. cepa (Darwin, 1854).

\section{Zonation of barnacle species with depth}

The depth profiles of the barnacle species collected during the two diving and the dredging expeditions are shown in Tables 13 and 14. There is distinct grouping, with intertidal, shallow subtidal and deeper subtidal communities recognisable. There are also clear distribution differences between intertidal/shallower water $(0-10 \mathrm{~m})$ and deeper water $\left(20-30^{+} \mathrm{m}\right)$ communities. The intertidal/ shallower water was richest, with a total of 23 species, whereas the deeper water sites were least rich (10 species) with the majority of sites dominated by only one or two species. The shallow water subtidal community $(11-20 \mathrm{~m})$ was somewhat intermediate (14 species), with some species wide-ranging.

\section{Checklist of barnacle species occurring in the waters of the Dampier Archipelago}

This checklist must still be considered incomplete until further identification of coral, sponge and gorgonian barnacles to species level occurs. Further collecting may reveal additional species, particularly subtidal and those epizoic on vertebrate hosts, e.g. turtles, sea-snakes, whales. A total of 49 barnacle species in 24 genera held in 11 families and four suborders is recorded (Appendix 2).

\section{Taxonomic affinities}

Of the 49 barnacle species recorded, nine are in the Pedunculata and the remaining 40 in the Sessilia. The nine pedunculate species are in seven genera held in five families within three suborders of the Pedunculata. The 40 sessile species belong to 17 genera within six families of one suborder of the Sessilia (Table 15).

\section{Biogeographic affinities}

Excluding 11 cosmopolitan species, the majority of Dampier Archipelago barnacles are tropical and either widely distributed throughout the Indo-West Pacific faunal province (26 species), or less broadly in the Indo-Australian sub-province of the IndoWest Pacific region (7 species). No species with Australasian (Australian/New Zealand affinities) were collected. Five species are possible Australian endemics (Table 15).

\section{DISCUSSION}

Barnacles are common in the waters of the Dampier Archipelago. They were collected from $69 \%$ of the diving and $41 \%$ of the dredging stations and are often conspicuous components of the intertidal rocky shore fauna. Thirty-five barnacles were collected during the fieldwork reported on herein and 49 species are now recorded from the area (Appendix 2).

Highest barnacle diversity was at intertidal sites on the Burrup Peninsula, on the mainland and in the northeast of the Dampier Archipelago. These sites are complex habitats (for example reef flats lined with igneous boulders beyond a mangal with a flowing creek and extensive tidal mudflats) and offer a large variety of substrata for barnacle attachment. Barnacles may be free-living, attached to hard substrata, commensal (e.g. associated within living hosts, such as sponges, gorgonians, coral) or epizoic (e.g. attached to living hosts, such as decapod crustaceans). Examples of complex habitats occur at Watering Cove on the Burrup Peninsula, Point Cleaverville on the mainland, and station DA1/98/11 on Dolphin Island.

Lowest intertidal barnacle diversity occurs where there are less complex habitats and fewer suitable attachment sites - for example, gently sloping limestone pavements with scattered loose slabs (Station DA3/98/48 Goodwyn Island), or silty, intertidal flats with scattered live and dead corals (DA1/98/23 Dolphin Island). A covering of short algal turf, e.g. Bornitella spp and Caulerpa spp, or rocks covered with filamentous brown algae, are often associated with these low barnacle diversity sites. Dampier Salt Ltd. Beach was found to be the least diverse mainland site. This is an area that has been subjected to recent anthropogenic influences, with the damming of a tidal creek and construction of a levy as part of the nearby Dampier Salt Ltd. operations.

Barnacle communities in the Dampier Archipelago zone on the basis of depth, with clear distribution differences demonstrated between intertidal and deepwater communities and the subtidal community somewhat intermediate. As on the shore, balanomorphs dominate depths to $>30 \mathrm{~m}$, following the general concept of this family's species richness in shallow waters (Newman and Ross, 1971; Young, 1995).

There is a gradual decrease in diversity from the 
intertidal and shallower subtidal to the deeper water habitats. Subtidally at $0-10 \mathrm{~m}$ depth, greatest barnacle diversity occurs at diving stations in the northeast of the Dampier Archipelago, e.g. Gidley and Angel Islands, and is associated with rich areas of soft corals, gorgonians, sea whips, sponges and corals. The least diverse stations form an outer arc, from the northeast to the southwest of the Dampier Archipelago. Between 11-20 m depth, the greatest diversity occurs at sites in the inner islands, e.g. dredging sites off Intercourse Island and the Malus Islands and a diving station in a channel between Enderby and West Lewis Islands. Again, these are areas where rich sponge gardens, gorgonians and corals occur. Species diversity below $20 \mathrm{~m}$ is low, with only one or two barnacle species being collected by diving and dredging from sites scattered throughout the archipelago. This low diversity reflects the lack of suitable hard substrata at these depths for barnacle attachment.

The shores of the Dampier Archipelago area are dominated by balanomorphs species. Chthamalamids, tetraclitids and balanids are the most widely-distributed intertidal barnacles, occurring throughout the archipelago, the Burrup Peninsula and the coast of the mainland. The zonation follows the chthamalid-tetraclitid-balanid trend which is characteristic of tropical and warm temperate Australian shores (Jones, 1992a, 2003) and is fairly universal on warm temperate shores (Foster, 1978). Two intertidal pedunculates, Lithotrya valentiana (Gray, 1825) and Ibla cumingi Darwin, 1851, also occur infrequently on the shores, in essentially refugial habitats.

The chthamalids Microeuraphia withersi (Pilsbry, 1916) and Caudoeuraphia cf. caudata (Pilsbry, 1916) occur in the upper to mid-littoral on sheltered shores, on rocks or mangroves (trunks and leaves of Avicennia marina (Forsk.) Vierh. and, less frequently, on the prop roots of Rhizophora stylosa Griff. In these areas, the cryptic Microeuraphia spp also occur in rock crevices and on the lower, shaded sides of rocks. Chthamalus malayensis Pilsbry, 1916 occurs on the upper surfaces of rocks on sheltered shores as well as in sheltered niches of more wave-exposed areas. The tetraclitids Tetraclita squamosa (Bruguière, 1789) and Newmanella vitiata (Darwin, 1854) occur on hard substrata in the mid to low littoral, in areas where there is semi to full wave exposure. Tetraclitella sp. nov. is hypobiotic, occurring on the undersides of stones and rocks and fouling mollusc shells, in the mid to sublittoral on sheltered or semi-sheltered shores. On these shores, the balanids Balanus amphitrite Darwin, 1854, B. reticulatus Utinomi, 1967 and, less frequently, B. cirratus Darwin, 1854 and Balanus sp. nov., also occur in the mid to sublittoral attached to rocks, mollusc shells, etc. In midlittoral areas, where there is intermediate to high wave exposure, the pedunculate Lithotrya valentiana (Gray,
1825) bores into limestone substrata and Ibla cumingi Darwin, 1851 occurs in crevices where it is often associated with mats of mussels, as well as between and under rocks and stones.

The sessile archaeobalanid genera Striatobalanus, Solidobalanus and Armatobalanus occur subtidally, and are prevalent in the dredging samples. Striatobalanus amaryllis (Darwin, 1854) is the most widely distributed subtidal species, attaching to a variety of substrata. Honeycombed limestone platforms, coral rubble and molluscs are preferred substrata for the more generalist barnacle genera Solidobalanus and Striatobalanus. Armatobalanus species are associated with coral rubble and also occur more infrequently on bivalve molluscs. The subtidal pedunculate, Calantica sp. nov. occurs attached to coral rubble.

Sessile commensal barnacles were collected subtidally from sponge, gorgonian and coral hosts by both the diving and dredging expeditions. Six specific taxa are presently recorded, but this number is an under-estimate of the diversity of these groups in the waters of the Dampier Archipelago. The taxonomy of Australian sponge (Acasta, Membranobalanus), gorgonian (Conopea) and coral (pyrgomatid) barnacles is at present undetermined and specimens in the present study have been identified, where possible, from existing literature or collections. However, many remain unidentified and are thus listed as Acasta spp, Conopea spp and pyrgomatid spp in Appendix 1. These collections are likely to contain a number of species which may prove to be new to science.

The pedunculate Octolasmis cf. bullata (Aurivillius, 1892) and two sessile species, Chelonibia patula (Ranzani, 1818) and C. cf. caretta (Spengler, 1790) are epizoic, i.e. attached to living substrata. Octolasmis cf. bullata (Aurivillius, 1892) occurs in the Dampier Archipelago attached to the gills of the brachyuran Portunus pelagicus (Linnaeus, 1758) and Chelonibia patula (Ranzani, 1818) attaches to the carapace of the same host. Chelonibia testudinaria (Linnaeus, 1758) and C. cf. caretta (Spengler, 1790) occur on the carapace of the Hawksbill Turtle, Eretmochelys imbricata (Borradaile).

\section{Introduced species}

In the waters of the Dampier Archipelago, six species recognised as intrôdüctioñ ầ ầ currently recorded. Of these, three (Balanus amphitrite Darwin, 1854, B. cirratus Darwin, 1854, B. trigonus Darwin, 1854) are well known, widely-distributed foulers whose ranges in Australian waters have probably been enhanced by shipping (Jones, 1992b). Balanus amphitrite and $B$. cirratus occur commonly in the intertidal throughout the Dampier Archipelago and the adjacent mainland; $B$. trigonus is less widely distributed and is recorded from only two sites (Appendix 2). 
In the present study, the first collections in the Dampier Archipelago of the circumtropical fouler Balanus reticulatus Utinomi, 1967 were made from a number of localities (Appendix 2). This species, which originated in Japan (Utinomi, 1967), has been collected from the North Barnard Islands, Queensland (Lewis, 1981) and from Yanchep Marina, Western Australia (Jones, 1992b). The present author has also recently recorded the species from Darwin (Northern Territory) as well as from immigrant boats, submarines and shipping visiting various Australian ports. Balanus reticulatus appears to be dominant in intertidal areas of Withnell Bay on the western lower Burrup Peninsula. It was also collected, but in lesser numbers, on the eastern side of the Burrup Peninsula (at Watering Cove), as well as throughout the Dampier Archipelago (Legendre, Dolphin, Angel and Wilcox Islands and Searipple Passage) and from mainland sites - at Cape Preston to the west and Point Cleaverville to the east, of the Dampier Archipelago. The means of introduction of $B$. reticulatus into the waters of the Dampier Archipelago are unknown, but Utinomi (1967) has suggested that ship transport is responsible for the widespread distribution of this Japanese species.

The megabalanines are well known fouling species occurring in tropical and warm temperate seas. Megabalanus tintinnabulum (Linnaeus, 1758), a wellknown cosmopolitan fouling species, occurs throughout the Dampier Archipelago on hard substrata, fouling animate (e.g. mollusc shells, decapod crustaceans) and inanimate (e.g. ropes, buoys, boats) surfaces in the low to sublittoral. Megabalanus tintinnabulum was first recorded in Western Australian waters in 1949 and now occurs in the vicinity of major ports (Jones, 1990, 1992b; Hass and Jones, 1999). The species has since been recorded by the present author from major ports in northern and eastern Australia. Jones (1990) suggested that the species is an introduction, most likely via shipping.

During the present study, another important fouling species, Megabalanus rosa (Pilsbry, 1916), was collected for the first time from three localities in the Dampier Archipelago; Hamersley Shoal (DA1/98/16), Legendre Island (DA1/98/27) and Georges Reef (DA3/99/42). Megabalanus rosa, a Japanese fouler, is previously recorded by a few specimens from western and eastern Australian waters (Jones et al., 1990; Jones, 1992b) and, more recently, by the present author from a number of major ports in northern and eastern Australia. Thirty species of marine organisms are now recorded as introduced into Western Australian waters, the majority being crustaceans (Jones, 1992b; Hass and Jones, 1999).

No data are available as to whether the presence of introduced barnacles in the Dampier area, or elsewhere in Western Australia or Australia, have caused any ecological consequences. Neither are data available as to whether introduced species have had any adverse impacts on native ones and thus any adverse impacts on biodiversity. However, the dominance of Balanus reticulatus Utinomi, 1967 in Withnell Bay and its presence in other areas of the Dampier Archipelago and the mainland is a situation that requires future long-term monitoring.

\section{Biogeographic affinities}

The barnacle fauna of the Dampier Archipelago is dominated by species with Indo-West Pacific and Indo-Australian distributions. The fauna shows many similarities with that of the Kimberley area (Jones, 1992a) to the north as well as affinities with those of the more southern Muiron Islands, Exmouth Gulf and the Montebello Islands (Jones and Berry, 2000) in tropical northern Western Australia (Jones, 2003). It differs significantly, however, from the barnacle fauna of the southern Australian warm temperate province (Jones, 1990; Jones, 2003). Compared to the northern Australian tropical province which has, as well as a high incidence of tropical species, a low species endemicity and high species diversity, the southern Australian warm-temperate province exhibits decreased species diversity, high species endemicity and a low incidence of tropical species (Jones, 2003).

\section{ACKNOWLEDGEMENTS}

I wish to acknowledge the extremely generous support from Woodside Energy Ltd. and their commitment to the partnership with the Western Australia Museum that resulted in the four-year study of the marine biodiversity of the waters of the Dampier Archipelago. I thank in particular Melissa Hewitt, as well as other participants in the study, who collected barnacle samples during the diving and dredging expeditions and Professor Brian Morton, The Swire Institute of Marine Science, The University of Hong Kong, for help with fieldwork during the shore surveys. The generosity of Mrs Angela Anderson and Dr Richard Anderson, who spent many hours of unpaid work sorting, bottling and databasing the barnacles collected during this study, is sincerely appreciated and acknowledged. Ben Radford, Geography Department, University of Western Australia, Perth, prepared Figure 1 and I sincerely thank him for his time and generosity.

The co-operation of the following colleagues who provided data on various cirripede collections in a number of Australian museums is also gratefully acknowledged - Dr Penny Berents (Australian Museum, Sydney, New South Wales), Dr Peter Davie (Queensland Museum, Brisbane, Queensland), Dr Gary Poore (Melbourne Museum, Melbourne, Victoria), Dr Barry Russell (Museum 
and Art Gallery of the Northern Territory) and Dr Wolfgang Zeidler (South Australian Museum, Adelaide, South Australia).

I also thank my colleagues, Professor John Buckeridge, Auckland University of Technology, Auckland, New Zealand, and Dr Paulo Young, Museu Nacional, Rio de Janeiro, Brazil, for their pertinent comments which significantly improved a draft of the manuscript.

\section{REFERENCES}

Broch, H. (1916). Results of Dr E. Mjöberg's Swedish Scientific Expeditions to Australia 1910-1913, No. VIII Cirripedien. Kungliga Svenska vetenskaps-akadamiens handlingar 52: 1-16.

Broch, H. (1922). Papers from Dr Th. Mortensen's Pacific Expedition 1914-1916. No. X. Studies on Pacific cirripeds. Videnskabelige Meddelelser fra Dansk Naturhistorisk Forening i Kjobenhavn 73: 215-358.

Foster, B.A. (1978). The Marine Fauna of New Zealand: Barnacles (Cirripedia: Thoracica). New Zealand Oceanographic Institute Memoir 69: 1-160. Wellington.

Hass, C.G. and Jones, D.S. (1999). Marine introductions to Western Australia, with a focus on crustaceans. Pp 37-44. In Kesby, J.A., Stanley, J.M., McLean, R.F. and Olive, L.J. (eds), Geodiversity: Readings in Australian geography at the close of the $20^{\text {th }}$ century. Special Publication Series No. 6: 1-630. Canberra, ACT, School of Geography and Oceanography, University College, Australian Defence Force Academy.

Hiro, F. (1936). Report on the Cirripedia collected in the Malayan waters by the ship "Zuihomaru". Japanese Journal of Zoology 6: 621-636.

Jones, D.S. (1990). The shallow-water barnacles of southern Western Australia. In Wells, F.E., Walker, D.I., Kirkman, H. and Lethbridge, R. (eds), Proceedings of the Third International Marine Biological Workshop: The Marine Flora and Fauna of Albany, Western Australia, 1988, 1: 333-437. Western Australian Museum, Perth.

Jones, D.S. (1992a). Part VI. Barnacles. In Morgan, G.J. (ed.), Survey of the Aquatic Fauna of the Kimberley Islands and Reefs, Western Australia. Report of the Western Australian Museum Kimberley Island and Reefs Expedition, August 1991: 50-56. Western Australian Museum, Perth.

Jones, D.S. (1992b). A review of Australian fouling barnacles. Asian Marine Biology 9: 89-100.

Jones, D.S. (2001). Introduced marine species in the Dampier Archipelago. 13 pp. Unpublished Report to Woodside Energy Ltd.

Jones, D.S. (2003). The biogeography of Western Australian shallow-water barnacles. In Wells, F.E., Walker, D.I. and Jones, D.S. (eds), Proceedings of the Eleventh International Marine Biological Workshop: The Marine Flora and Fauna of Dampier, Western Australia 2: 479-496. Western Australian Museum, Perth.
Jones, D.S. and Berry, P.F. (2000). Crustacea of the Montebello Islands. In Berry, P.F. and Wells, F.E. (eds), Survey of the Marine Fauna and Habitats of the Montebello Islands, Western Australia. Records of the Western Australian Museum, Supplement 59: 59-63.

Jones, D.S. and Hewitt, M.A. (1996). Barnacles (Cirripedia). In Hutchins, J.B., Slack-Smith, S.M., Bryce, C.W., Morrison, S.M. and Hewitt, M.A. (eds), Marine Biological Survey of the Muiron Islands and the eastern shore of Exmouth Gulf. Report to the Ocean Rescue 2000 Program (Project number G0012/94), February, 1996: 44-53. Western Australian Museum, Perth.

Jones, D.S. and Hewitt, M.A. (1997). Barnacles (Cirripedia). In Walker, D.I. (ed.), Marine Biological Survey of the Central Kimberley Coast, Western Australia (National Estates Grant Program Project), December, 1996: 91-95. University of Western Australia, Perth.

Jones, D.S., Anderson, J.T. and Anderson, D.T. (1990). Checklist of the Australian Cirripedia. Technical Reports of the Australian Museum 3: 1-38.

Krüger, P. (1911). In Doflein, F. (ed.), Beiträge zur Cirripedienfauna ostasiens. Beiträge zur Naturgeschichte ostasiens. Abhandlungen der Kongelige Bayerischen Akademie der Wissenschaften, Mathematischephysikalische Klasse, Supplement-Band 2: 1-72.

Lewis, J.A. (1981). Settlement of fouling organisms at the ITTRE North Barnard Island Raft Site. Department of Defence: Defence Science and Technology Organisation, Materials Research Laboratories, Melbourne. Report MRL-TN-450.

Newman, W.A. (1996). Sous-classes des Cirripèdes (Cirripedia Burmeister, 1834). Super-ordres des thoraciques et des acrothoraciques (Thoracica Darwin, 1954 - Acrothoracica Gruvel, 1905). In, Traité de Zoologie, Anatomie, Systématique, Biologie, 7, Crustacés, Fascicule 2 Généralités (suite) et Systématique: 453-540. Masson, Paris.

Newman, W.A. and Ross, A. (1971). Antarctic Cirripedia. Antarctic Research Series 14: 1-257. American Geophysical Union, Washington.

Nilsson-Cantell, C.-A. (1921). Cirripeden-Studien. Zur kenntnis der Biologie, Anatomie und Systematik dieser Gruppe. Zoologiska bidrag fran Uppsala 7: 75395.

Utinomi, H. (1967). Comments on some new and already known cirripeds with emended taxa, with special reference to the parietal structure. Publications of the Seto Marine Biological Laboratory 15: 199-237.

Weltner, W. (1897). Verzeichnis der bisher beschriebenen recenten Cirripedien-Arten. Mit Angabe der im Berliner Museum vorhandenen species und ihrer fundorte. Archiv fur naturgeschichte.63:.227-280.

Young, P.S. (1995). New interpretations of South American patterns of barnacle distribution. In Schram, F. and Høeg, J. (eds), New Frontiers in Barnacle Biology, Crustacean Issues: 229-253. A. A. Balkema, Rotterdam. 
Table 1 Additional barnacle species obtained during shore collections.

\begin{tabular}{|c|c|c|c|c|c|c|c|c|c|}
\hline \multirow[b]{2}{*}{ Genus } & \multirow[b]{2}{*}{ Species } & \multicolumn{4}{|c|}{ Mainland } & \multicolumn{3}{|c|}{ Burrup Pen. } & \multirow[t]{2}{*}{ Total } \\
\hline & & $C P$ & DS & DB & $\mathrm{PC}$ & WB & WC & $\mathrm{CC}$ & \\
\hline Ibla & camingi & & & & & & 1 & 1 & 2 \\
\hline Octolasmis & cf. bullata & & & & & & 1 & & 1 \\
\hline Caudoemonphin & cf. cautatn & & & 1 & 1 & 1 & 1 & & 4 \\
\hline Microeseraphia & withersi & & & & & 1 & 1 & & 2 \\
\hline Microeuraphin & sp. 1 & & & 1 & & & & & 1 \\
\hline Microeuraphin & sp. 2 & & & 1 & & & & & 1 \\
\hline Chthomalus & malaventis & 1 & & 1 & 1 & 1 & 1 & & 5 \\
\hline Chelonibin & cf circtin & & & & & & 1 & & 1 \\
\hline Cholonibin & patula & 1 & & & & & 1 & & 2 \\
\hline Tetraclitella & sp. nov. & 1 & & 1 & 1 & & 1 & 1 & 5 \\
\hline Newmanella & witiata & & 1 & 1 & 1 & & 1 & & 4 \\
\hline Tetradita & soflamosa & 1 & & & 1 & 1 & 1 & 1 & 5 \\
\hline Armatobalanus & quadrioittatus & & & & & & 1 & & 1 \\
\hline Acastia & spp & & & & & & 1 & & 1 \\
\hline Balanus & amphitrite & & 1 & 1 & 1 & 1 & 1 & 1 & 6 \\
\hline Balanus & reticulatus & 1 & & & 1 & 1 & 1 & & 4 \\
\hline Balanus & cirratus & 1 & 1 & 1 & 1 & 1 & 1 & & 6 \\
\hline Balnmus & sp. nov. & & & & 1 & 1 & 1 & 1 & 4 \\
\hline Megabalanus & cf. ajax & & & & & & 1 & & 1 \\
\hline Total & 19 & 6 & 3 & 8 & 9 & 8 & 17 & 5 & 56 \\
\hline
\end{tabular}

$\mathrm{CC}=$ Cowrie Cove; $\mathrm{DB}=$ Dampier Beach; $\mathrm{PC}=$ Point Cleaverville; $W \mathrm{~B}=$ Withnell Bay; $\mathrm{CP}=$ Cape Preston; $\mathrm{DS}=\mathrm{Dampier}$ Salt Ltd; WC $=$ Watering Cove

Table 2 Intertidal barnacle diversity (combined data from DA1/98 and DA3/99 intertidal stations plus additional shore collections).

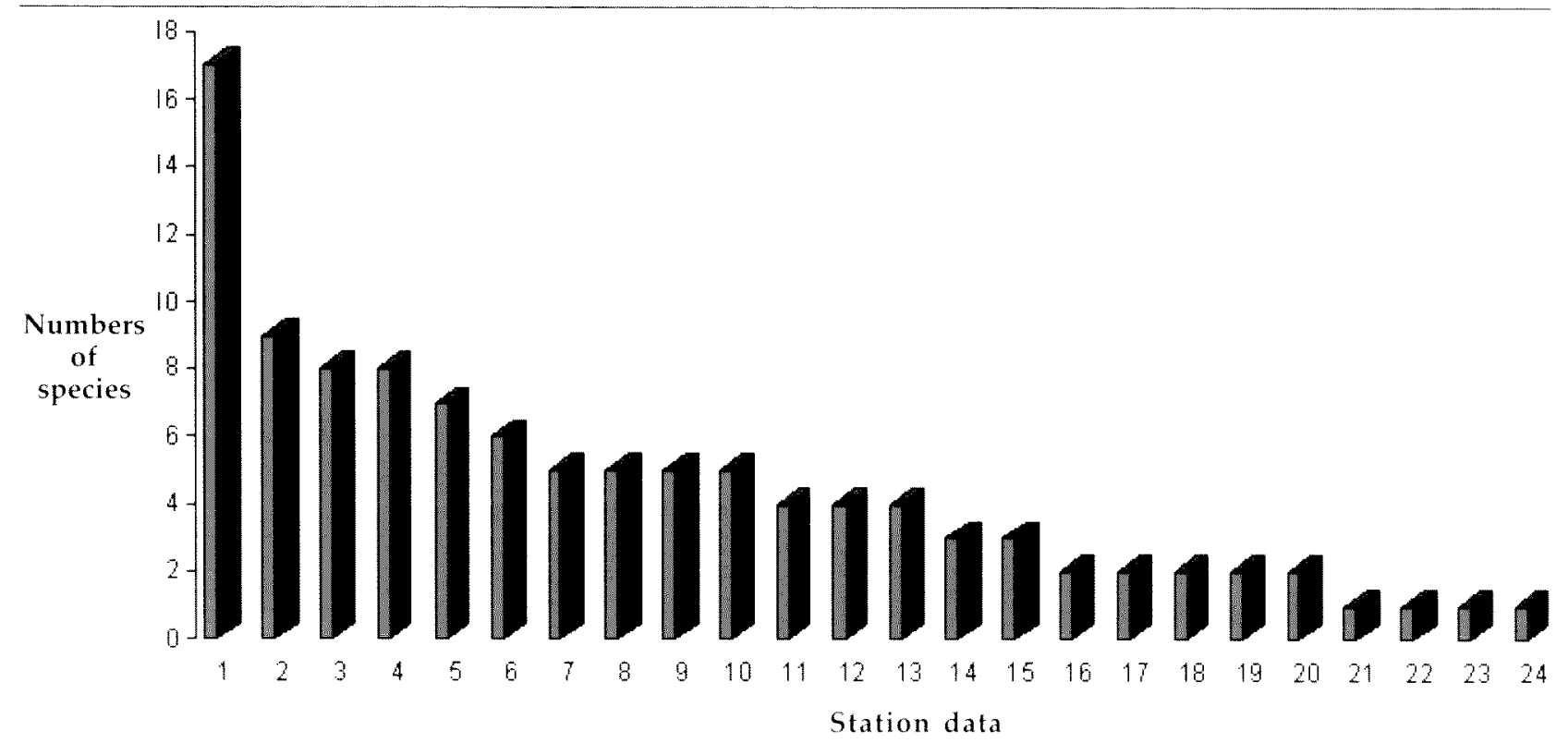

1. Watering Cove

2. Point Cleaverville

3. Dampier Beach

4. Withnell Bay
5. DA1/98/11

6. Cape Preston

7. Cowrie Cove

8. DA1/98/02
9. DAl/98/31

10. DA3/98/54

11. DA $1 / 98 / 17$

12. DA $3 / 98 / 42$
13. $0 A 3 / 98 / 66$

14. Dampier Salt

15. DA3/98/45

16. DAl/98/14
17. DA $3 / 98 / 48$

18. DA3/98/51

19. DA3/98/59

20. DA $3 / 98 / 62$
21. $\mathrm{DAl} / 98 / 20$

22. DA1/98/23

23. DAl/98/34

24. 0 A $3 / 98 / 38$ 
Table 3 The distributions by station of intertidal barnacle species (additional intertidal collections).

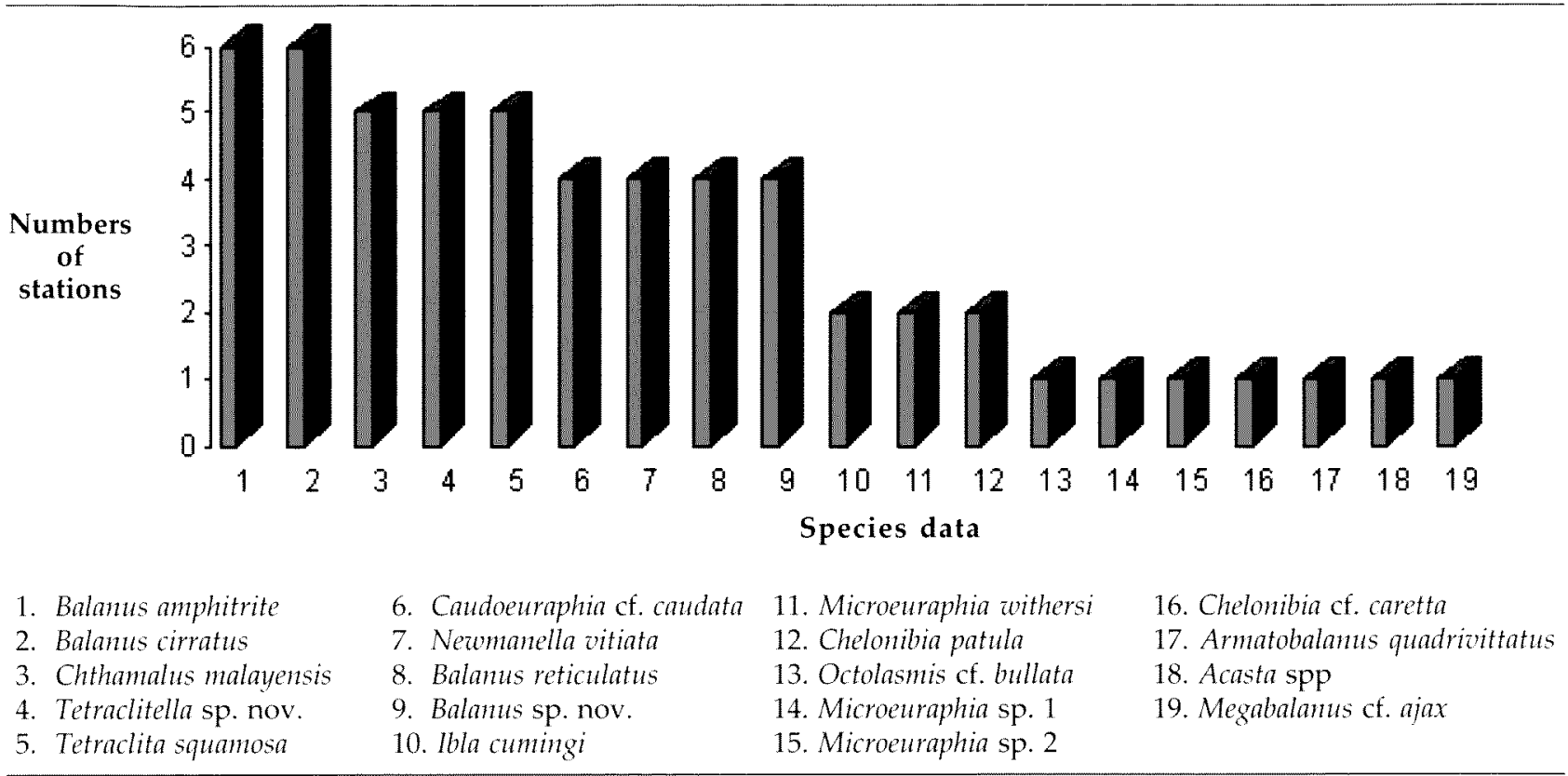


Table 4 Barnacles collected by the DA1/98 diving expedition.

\begin{tabular}{|c|c|c|c|c|c|c|c|c|c|c|c|c|c|c|c|c|c|c|c|c|c|c|c|c|c|c|c|c|c|}
\hline \multicolumn{2}{|l|}{ Station No. } & \multirow[t]{2}{*}{1} & \multirow[t]{2}{*}{2} & \multirow[t]{2}{*}{3} & \multirow[t]{2}{*}{4} & \multirow[t]{2}{*}{6} & \multirow[t]{2}{*}{7} & \multirow[t]{2}{*}{8} & \multirow[t]{2}{*}{9} & \multirow[t]{2}{*}{10} & \multirow[t]{2}{*}{11} & \multirow[t]{2}{*}{12} & \multirow[t]{2}{*}{13} & \multirow[t]{2}{*}{14} & \multirow[t]{2}{*}{16} & \multirow[t]{2}{*}{17} & \multirow[t]{2}{*}{20} & \multirow[t]{2}{*}{21} & \multirow[t]{2}{*}{23} & \multirow[t]{2}{*}{24} & \multirow[t]{2}{*}{26} & \multirow[t]{2}{*}{27} & \multirow[t]{2}{*}{30} & 31 & 32 & 33 & 34 & 35 & Total \\
\hline Genus & Species & & & & & & & & & & & & & & & & & & & & & & & & & & & & \\
\hline Ibla & cumingi* & & 1 & & & & 1 & & & & & & & & & & & & & & & 1 & & & & & & & 3 \\
\hline Caudoeturaphia & cf. caudata* & & & & & & & & & & 1 & & & 1 & & & & & & & & 1 & & 1 & & & 1 & & 5 \\
\hline Chthamalus & malayensis* & & & & & & 1 & & & & 1 & & & & & & & & & & & 1 & & & & & & & 3 \\
\hline Tetraclitella & sp. nov. & & 1 & & & & 1 & & & 1 & & & & & & & & & & & & 1 & & & & & & & 4 \\
\hline Newmanella & vitiata* & & 1 & & & & & & & 1 & 1 & & & & & & & & 1 & & & & & & & & & 1 & 5 \\
\hline Tetraclita & squamosa* & & & & & & 1 & & & & 1 & & & & & & & & & & & 1 & & 1 & & & & & 4 \\
\hline Armatobalamus & cf. cepa & & & & & & & 1 & & & & & & & & & & & & & & & 1 & 1 & & & & & 3 \\
\hline Armatobalamus & quadrivittatus & & & & & & & & & & & & 1 & & & & & & & & & & & & & 1 & & & 2 \\
\hline Stratobalamus & amaryllis & & & & & & & & & & & & & & & 1 & & & & & & & 1 & & & 1 & & & 3 \\
\hline Striatobalamus & tenutis & & & & & & & & & & & & & & & & & & & & & & 1 & & & & & & 1 \\
\hline Conopea & spp & & & & & & & & & & & & & & & 1 & & & & & 1 & 1 & & & & 1 & & & 4 \\
\hline Acasta & spp & 1 & & 1 & & 1 & & 1 & & & & 1 & & & 1 & & 1 & 1 & & 1 & & & 1 & & 1 & 1 & & & 12 \\
\hline Pyrgomatid & spp & 1 & & 1 & 1 & & & 1 & & 1 & & & 1 & & & & & & & & & & & & & 1 & & & 7 \\
\hline Balanus & amphitrite ${ }^{*}$ & & 1 & & & & & & & & 1 & & & & & & & & & & & & & & & & & & 2 \\
\hline Balanus & reticulatus* & & 1 & & & & & 1 & 1 & 1 & 1 & & & & & 1 & & & & & & 1 & & 1 & & & & & 8 \\
\hline Balanus & cirratus* & & & & & & & & 1 & & & & & & & & & & & & & 1 & , & & & & & & 2 \\
\hline Balanus & sp. nov * & & & & & & & & & & 1 & & & & & & & & & & & 1 & & 1 & & & & & 3 \\
\hline Megabalanus & rosa & & & & & & & & & & & & & & 1 & & & & & & & 1 & & & & & & & 2 \\
\hline Megabalants & tintinnabulum & & & 1 & 1 & & 1 & & & & & & & 1 & & 1 & & & & 1 & & 1 & & & & & & & 7 \\
\hline Total & 19 & 2 & 5 & 3 & 2 & 1 & 5 & 4 & 2 & 4 & 7 & 1 & 2 & 2 & 2 & 4 & 1 & 1 & 1 & 2 & 1 & 11 & 4 & 5 & 1 & 5 & 1 & 1 & \\
\hline
\end{tabular}

*intertidal species 
Table 5 Barnacles collected by the DA3/99 diving expedition.

\begin{tabular}{|c|c|c|c|c|c|c|c|c|c|c|c|c|c|c|c|c|c|c|c|c|c|c|c|}
\hline & Station No. & 37 & 38 & 39 & 41 & 42 & 45 & 48 & 49 & 50 & 51 & 52 & 53 & 54 & 55 & 56 & 57 & 59 & 62 & 63 & 65 & 66 & Total \\
\hline Genus & Species & & & & & & & & & & & & & & & & & & & & & & \\
\hline Ibla & cumingi ${ }^{*}$ & & & & & & 1 & & & & & & & & & & & & & & & 1 & 2 \\
\hline Lithotrya & valentiana ${ }^{*}$ & & & & & & & 1 & & & & & & & & & & & & & & & 1 \\
\hline Caudoeuraphia & cf. caudata & & & & & & & & & & & & & 1 & & & & & & & & 1 & 2 \\
\hline Chthamalus & malayensis* & & & & & & 1 & & & & & & & 1 & & & 1 & & & & & 1 & 4 \\
\hline Tetraclitella & sp. nov.* & & & & & 1 & & & & & & & & 1 & & & 1 & 1 & 1 & & & & 5 \\
\hline Newmanella & vitiata $^{*}$ & & 1 & & & & & & & & 1 & & & & & & & & & & & & 2 \\
\hline Tetraclita & squamosa $a^{*}$ & & & & & 1 & 1 & 1 & & & 1 & & & & & & & 1 & & & & & 5 \\
\hline Armatobalanus & quadrivittatus & & & & & & & & & 1 & & & & & & & & & & & & & 1 \\
\hline Striatobalanus & amaryllis & & & & 1 & & & & & & & & & & 1 & & & & & & & & 2 \\
\hline Conopea & spp & & & & & & & & & & & 1 & & & 1 & 1 & 1 & & & & 1 & & 5 \\
\hline Acasta & spp & 1 & & & 1 & & & & & & & & & & 1 & & & & & 1 & 1 & & 5 \\
\hline Pyrgomatid & spp & & & 1 & & & & & 1 & & & & 1 & & 1 & & & & & & & & 4 \\
\hline Balamis & amphitrite $^{*}$ & & & & & & & & & & & & & 1 & & & & & 1 & & & & 2 \\
\hline Balantes & reticulatus* & & & & & & & & & & & & & & & 1 & & & & & & & 1 \\
\hline Balanus & cirratus $^{*}$ & & & & & & & & & & & & & & & 1 & & & & & & & 1 \\
\hline Balanus & sp. nov.* & & & & & & & & & & & & & 1 & 1 & & & & & & & 1 & 3 \\
\hline Megabalanus & rosa & & & & & 1 & & & & & & & & & & & & & & & & & 1 \\
\hline Megabalanus & tintinnabulum & & & 1 & & 1 & & & & & & & & & & & & & & & & & 2 \\
\hline Total & 18 & 1 & 1 & 2 & 2 & 4 & 3 & 2 & 1 & 1 & 2 & 1 & 1 & 5 & 5 & 3 & 3 & 2 & 2 & 1 & 2 & 4 & \\
\hline
\end{tabular}

*intertidal species 
Table 6 Comparison of barnacle species collected by the diving (DA1/98, DA3/99) and dredging (DA2/99) expeditions and additional shore collecting.

\begin{tabular}{|c|c|c|c|c|}
\hline \multirow[b]{2}{*}{ Species } & \multicolumn{2}{|c|}{ Diving } & \multirow{2}{*}{$\frac{\text { Dredging }}{\text { DA2 }}$} & \multirow[t]{2}{*}{ Mainland Shores } \\
\hline & DA1 & DA3 & & \\
\hline Ibla cumingi* Darwin, 1851 & 1 & 1 & & 1 \\
\hline Octolasmis cf. bullata (Aurivillius, 1892) & & & & 1 \\
\hline Calantica sp. nov. & & & 1 & \\
\hline Lithotrya valentiana* (Gray, 1825$)$ & & 1 & & \\
\hline Caudoeuraphia of. caudata* ${ }^{*}$ Pilsbry, 1916) & 1 & 1 & & 1 \\
\hline Microeuraphia withersi ${ }^{*}$ (Pilsbry, 1916) & & & & 1 \\
\hline Microeuraphia sp. $1^{*}$ & & & & 1 \\
\hline Microeuraphiasp. $2^{*}$ & & & & 1 \\
\hline Chthamalus malayensis* Pilsbry, 1916 & 1 & 1 & & 1 \\
\hline Chelonibia cf. caretta (Spengler, 1790) & & & & 1 \\
\hline Chelonibia patula (Ranzani, 1818) & & & & 1 \\
\hline Tetraclitella sp. now. ${ }^{*}$ & 1 & 1 & & 1 \\
\hline Newmanella vitiata ${ }^{*}($ Darwin, 1854$)$ & 1 & 1 & & 1 \\
\hline Tetraciita squamosa* (Bruguière, 1789) & 1 & 1 & & 1 \\
\hline Armatobalanus arcuatus Hoek, 1913 & & & 1 & \\
\hline Armatobalanus cf. cepa (Darwin, 1854) & 1 & & & \\
\hline Armatobalanus quadrivittatus (Darwin, 1854) & 1 & 1 & 1 & 1 \\
\hline Armatobalanus terebratus (Darwin, 1854) & & & 1 & \\
\hline Solidobalanus ciliatus (Hoek, 1913) & & & 1 & \\
\hline Striatobalanus amaryllis (Darwin, 1854) & 1 & 1 & 1 & \\
\hline Striatobalanus bimae (Hoek, 1913) & & & 1 & \\
\hline Striatobalanus tenuis (Hoek, 1883) & 1 & & 1 & \\
\hline Conopea calceolus (Ellis, 1758) & & & 1 & \\
\hline Conopea sp. 1 cf. navicula (Darwin, 1854) & & & 1 & \\
\hline Conopea sp. 2 cf. dentifer (Broch, 1922) & & & 1 & \\
\hline Conopeaspp & 1 & 1 & 1 & \\
\hline Acasta spp & 1 & 1 & 1 & 1 \\
\hline Pyrgomatid spp & 1 & 1 & 1 & \\
\hline Balanus amphitrite ${ }^{*}$ Darwin, 1854 & 1 & 1 & & 1 \\
\hline Balanus reticulatus ${ }^{\text {Utinomi, } 1967}$ & 1 & 1 & & 1 \\
\hline Balanus cirratus* Darwin, 1854 & 1 & 1 & & 1 \\
\hline Balanus sp. nov. ${ }^{*}$ & 1 & 1 & & 1 \\
\hline Megabalanus cf. ajax (Darwin, 1854) & & & & 1 \\
\hline Megabalanus rosa (Pilsbry, 1916) & 1 & 1 & & \\
\hline Megabalanus tintinnabulum (Linnaeus, 1758) & 1 & 1 & & \\
\hline Total & 19 & 18 & 14 & 19 \\
\hline
\end{tabular}

\footnotetext{
* intertidal species
} 
Table 7 Subtidal barnacle diversity, DA1/98 and DA3/99 diving expeditions.

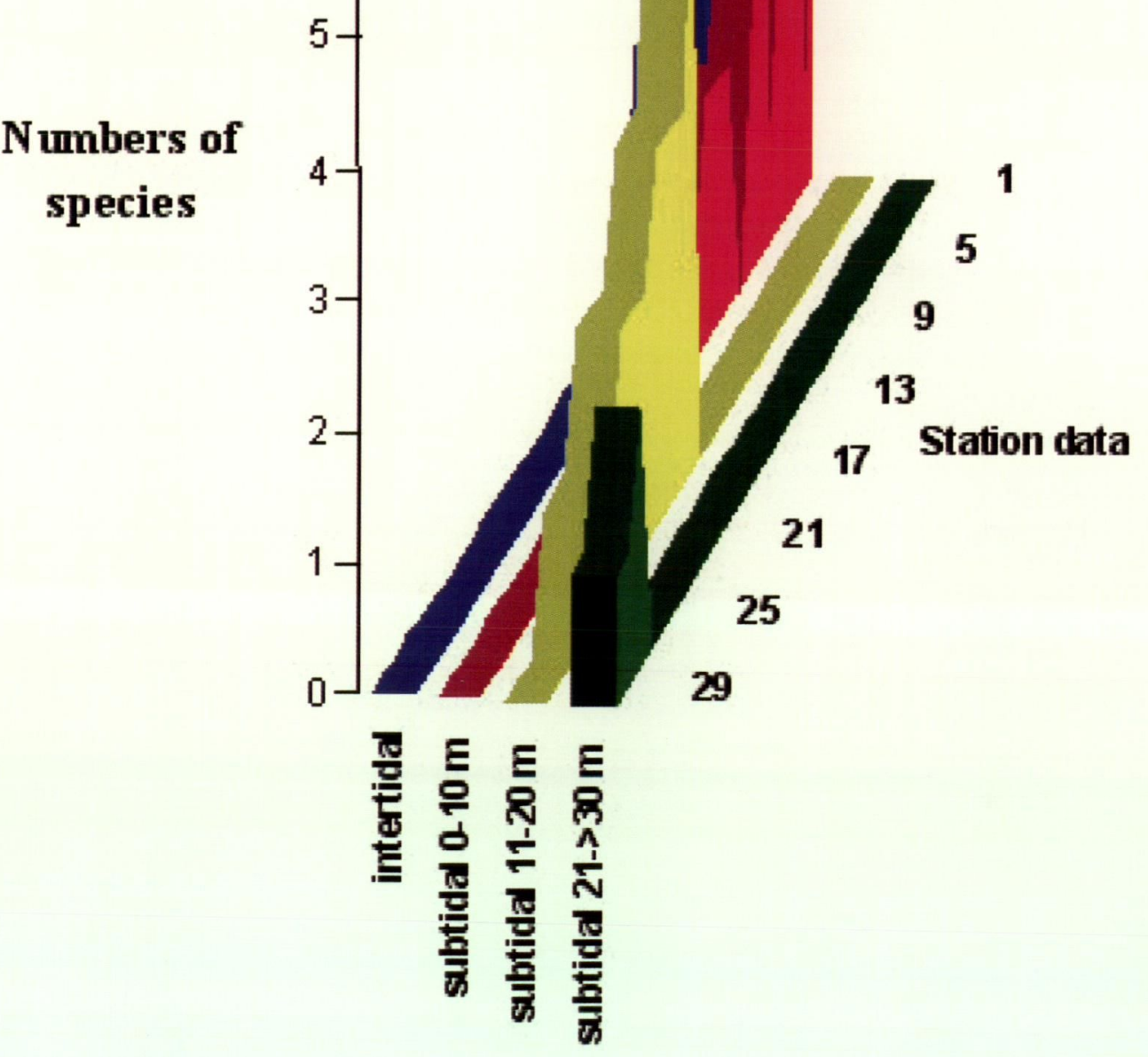

1. DA1 $/ 98 / 27$

2. DA1 $/ 98 / 07$

3. DA1/98/33

4. DA $1 / 98 / 08$

5. DA $1 / 98 / 10$
6. DA1/98/30
7. DA $1 / 98 / 01$
8. DA1/98/09
9. DA1/98/16
10. DA1/98/24

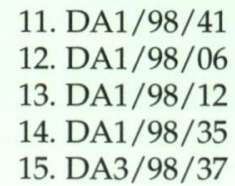

16. DA3/98/49

17. DA3/98/53

18. DA3/99/55

19. DA1/98/03

20. DA3/99/56
21. DA3/99/57

22. DA1/98/04

23. DA1/98/13

24. DA1/98/16

25. DA $1 / 98 / 21$
26. DA1/98/32

27. DA3/99/50

28. DA3/99/39

29. DA1/98/26

30. DA3/99/52 
Table 8 Intertidal barnacle species distributions (DA1/98 and DA3/99 diving expeditions).

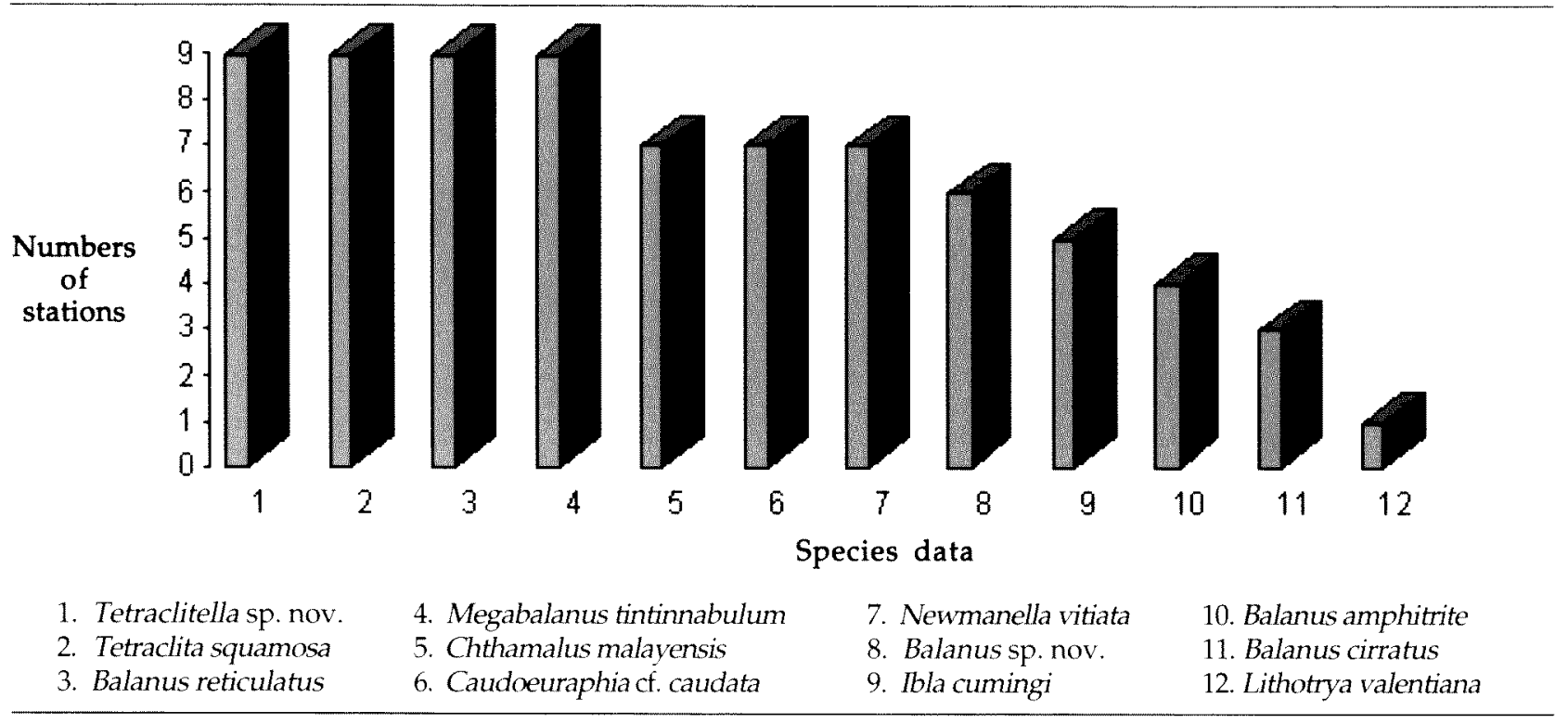

Table 9 Subtidal barnacle species distributions (DA1/98 and DA3/99 diving expeditions).

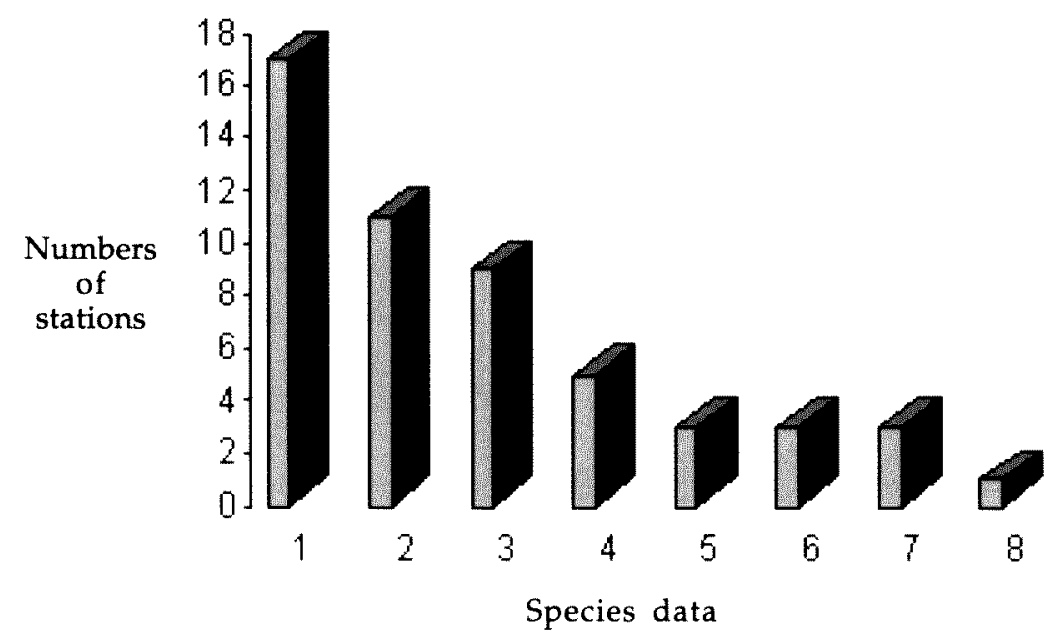
1 Acasta spp
5. Armatobalanuscf. cepa
2. Pyrgomatid spp
6. Armatobalanus quadrivittatus
3. Conopeaspp
7. Megabalaus rosa
4. Striatobalanus amaryllis
8. Striatobalanus tenuis 
Table 10 Barnacles collected by the DA2/99 dredging expedition.

\begin{tabular}{|c|c|c|c|c|c|c|c|c|c|c|c|c|c|c|c|c|c|c|c|c|c|c|c|c|c|c|}
\hline & Station No. & 4 & 5 & 6 & 8 & 9 & 10 & 12 & 13 & 24 & 29 & 33 & 34 & 35 & 37 & 40 & 42 & 46 & 47 & 49 & 50 & 51 & 56 & 57 & 59 & 62 \\
\hline Genus & Species & & & & & & & & & & & & & & & & & & & & & & & & & \\
\hline Calantica & sp. nov. & & & & & & & & 1 & & & & & & & & & & & & & & & & & \\
\hline Armatobalanus & arcuatus & & & & & & & & & & & & & & & & & & & & & & & 1 & & \\
\hline Armatobalanus & quadrivittatus & & & & & & & & & & & & & & & & & & & & & & & & & \\
\hline Armatobalanus & terebratus & & & & & & & & & & & & & & & & & & & & & & & & & 1 \\
\hline Solidobalanus & ciliatus & & & & & & & & 1 & & & & & & & & & & & & & & & & & \\
\hline Striatobalanus & amaryllis & & & 1 & 1 & 1 & 1 & 1 & & & 1 & 1 & & 1 & 1 & 1 & 1 & 1 & 1 & 1 & 1 & 1 & 1 & 1 & 1 & 1 \\
\hline Striatobalanus & bimae & & & & & & & & & & & 1 & & & & & & & & & & & & & & \\
\hline Striatobalanus & tenuis & & & & & & & & & 1 & & & & & & & & & & & & & & & & \\
\hline Conopea & calceolus & & 1 & & & 1 & & & 1 & & 1 & 1 & & & & & & & & 1 & & & & & 1 & \\
\hline Conopea & sp. $1 \mathrm{cf}$. navicula & & & & & & & & & & & & & & & & & & & & & & & & & \\
\hline Conopea & sp. 2 cf. dentifer & & & & & & & & & & & & & & & & & & & & & & & & & \\
\hline Conopea & spp & 1 & 1 & & & & & & 1 & & & & & & & & & & & & & & & & & 1 \\
\hline Acasta & spp & & & & & & 1 & & & & & 1 & 1 & & 1 & & 1 & & & & 1 & & & & & \\
\hline Pyrgomatid & spp & & & & & & & & 1 & & & 1 & & & & & & & & & & & & & & \\
\hline Total & 14 & 1 & 2 & 1 & 1 & 2 & 2 & 1 & 5 & 1 & 2 & 5 & 1 & 1 & 2 & 1 & 2 & 1 & 1 & 2 & 2 & 1 & 1 & 2 & 2 & 3 \\
\hline
\end{tabular}


Table 11 Subtidal barnacle diversity, DA2/99 dredging expedition.

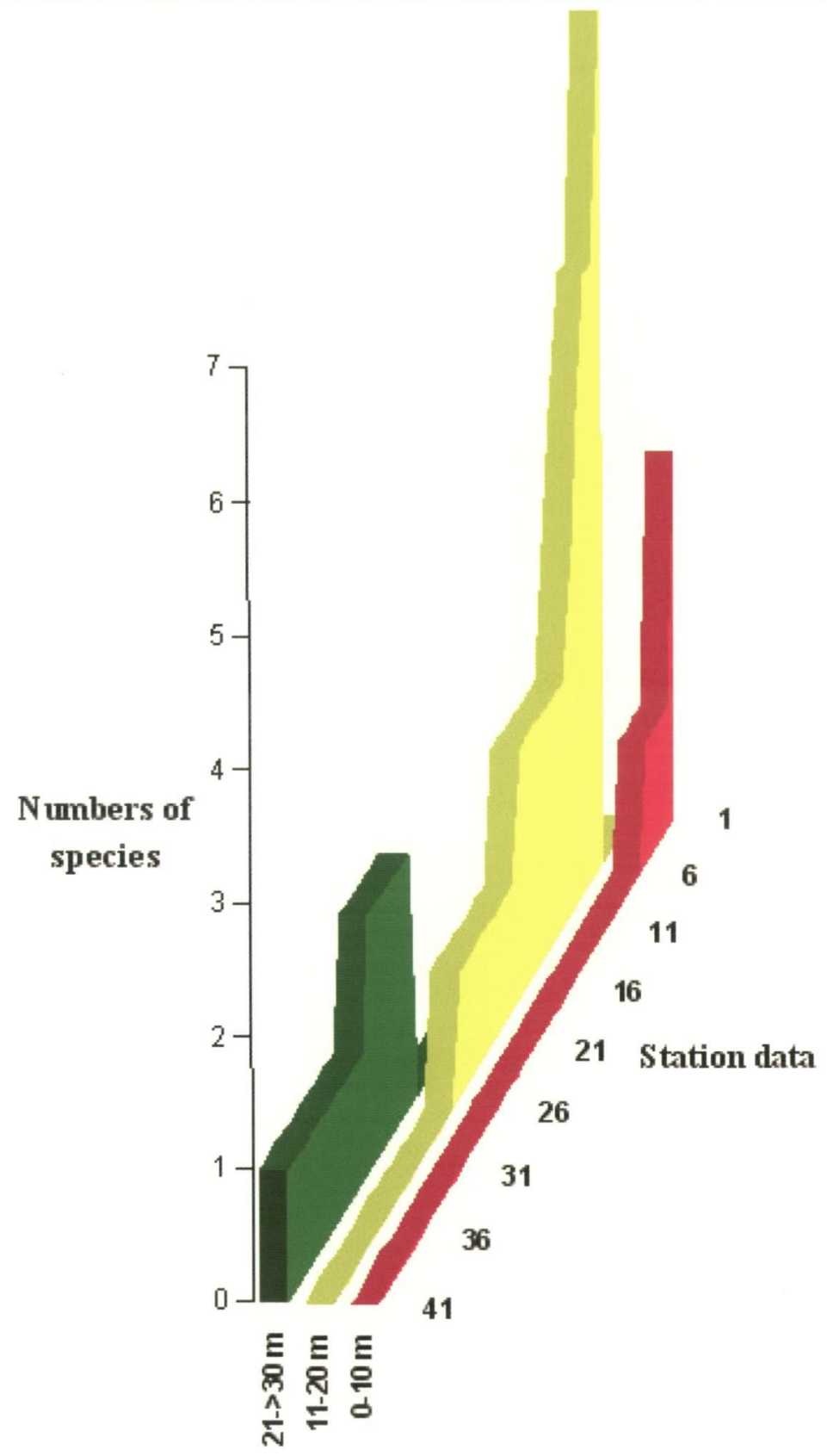

1. DA2/99/62
2. DA2/99/66

6. DA2/99/65

7. DA2/99/13

8. DA2/99/33

9. DA2/99/75

10. DA2/99/74

26. DA3/99/05

27. DA3/99/09

28. DA3/99/10

29. DA3/99/29
3. DA2/99/68

4. $\mathrm{DA} 2 / 99 / 72$

11. DA2/99/37

12. DA2/99/42

13. DA2/99/49

14. DA2/99/59

15.DA2/99/84

30. DA3/99/50

31. DA3/99/57

32. DA3/99/04

33. DA3/99/06
0-10 m

5. DA2/99/96

11-20 m
16. DA2/99/94
17. DA2/99/99
18. DA2/99/34
19. DA2/99/35
20. DA2/99/40
21. DA2/99/46
22. DA2/99/51
23. DA2/99/73
24. DA2/99/76
25. DA2/99/83

21->30 m
34. DA3/99/08
35. DA3/99/12
36. DA3/99/24
37. DA3/99/47
38. DA3/99/56
39. DA3/99/82
40. DA3/99/88
41. DA3/99/90 
Table 12 Subtidal barnacle species distributions, DA2/99 dredging expedition.

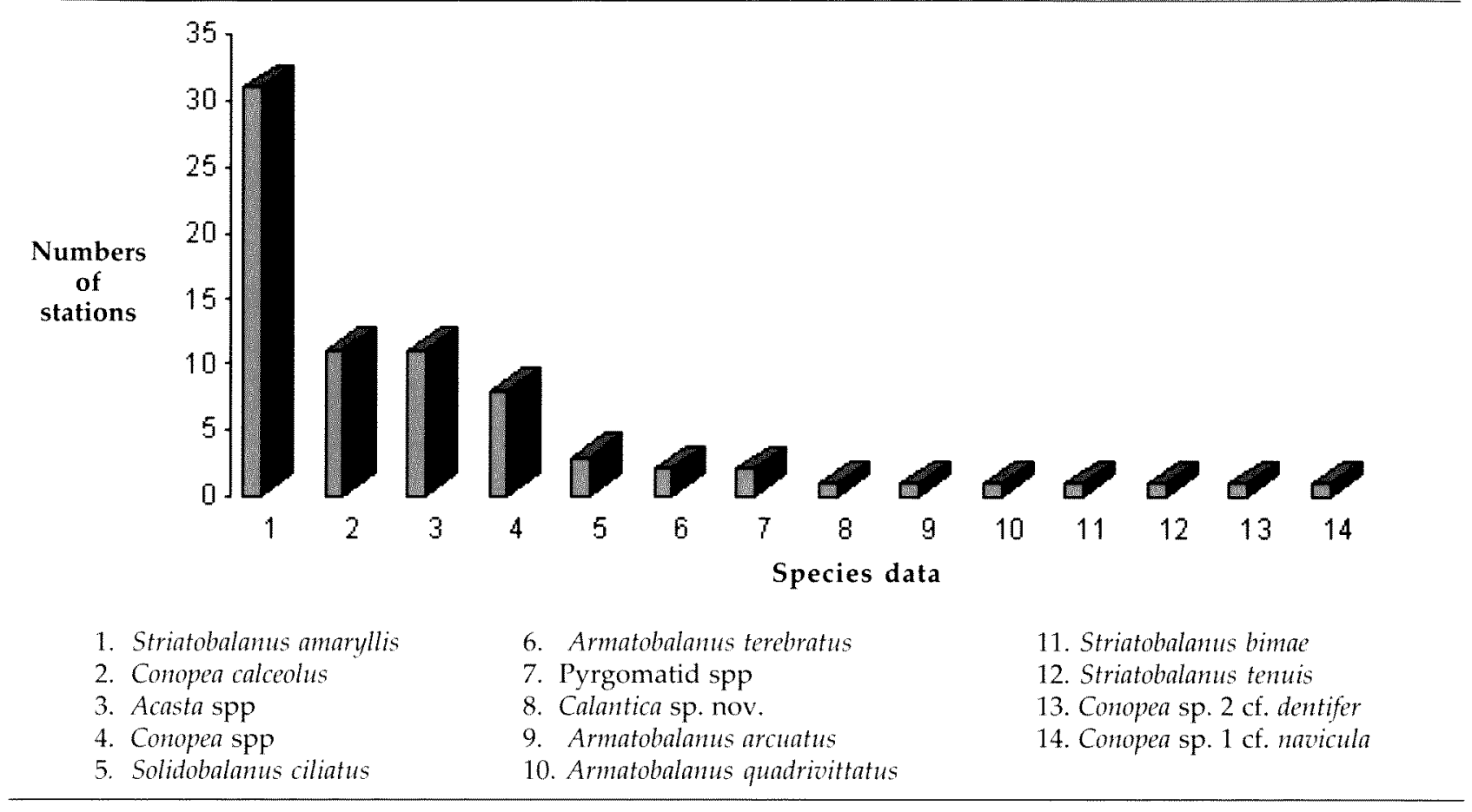

Table 13 Zonation of barnacle species with depth in the Dampier Archipelago, Western Australia.

\begin{tabular}{|c|c|c|c|c|}
\hline Genus & Species & $\begin{array}{c}\text { Depth (m) } \\
0-10\end{array}$ & $\begin{array}{c}\text { Depth (m) } \\
\quad 11-20\end{array}$ & $\begin{array}{c}\text { Depth }(\mathrm{m}) \\
\mathbf{2 1 - > 3 0}\end{array}$ \\
\hline Lithotrya & valentiana* & + & & \\
\hline Ibla & cumingi* $^{*}$ & + & & \\
\hline Caudoeuraphia & cf. caudata* & + & & \\
\hline Newmanella & vitiata $^{*}$ & + & & \\
\hline Balanus & amphitrite $^{*}$ & + & & \\
\hline Tetraclita & squamosa ${ }^{*}$ & + & & \\
\hline Megabalanus & rosa & + & & \\
\hline Armatobalanus & cf. cepa & + & & \\
\hline Chthamalus & malayensis* & + & & \\
\hline Balanus & sp. nov.* & + & & \\
\hline Tetraclitella & sp. nov.* & + & & \\
\hline Balanus & reticulatus* & + & & \\
\hline Balanus & cirratus* & + & & \\
\hline Solidobalanus & ciliatus & + & + & \\
\hline Armatobalanus & terebratus & + & + & \\
\hline Calantica & sp. nov. & & + & \\
\hline Conopea & sp. 1 cf. navicula & & + & \\
\hline Conopea & sp. 2 cf. dentifer & & + & \\
\hline Megabalanus & tintinnabulum & + & + & + \\
\hline Armatobalanus & quadrivittatus & + & + & + \\
\hline Pyrgomatid & spp & + & + & + \\
\hline Acasta & spp & + & + & + \\
\hline Striatobalantus & tenuis & + & + & + \\
\hline Striatobalanus & amaryllis & + & + & + \\
\hline Conopea & calceolus & + & + & + \\
\hline Conopea & spp & + & + & + \\
\hline Striatobalanus & bimae & & + & + \\
\hline Armatobalanus & arcuatus & & & + \\
\hline Total & 28 & 23 & 14 & 10 \\
\hline
\end{tabular}

\footnotetext{
* intertidal species
} 
Table 14 Variation in barnacle diversity with depth.

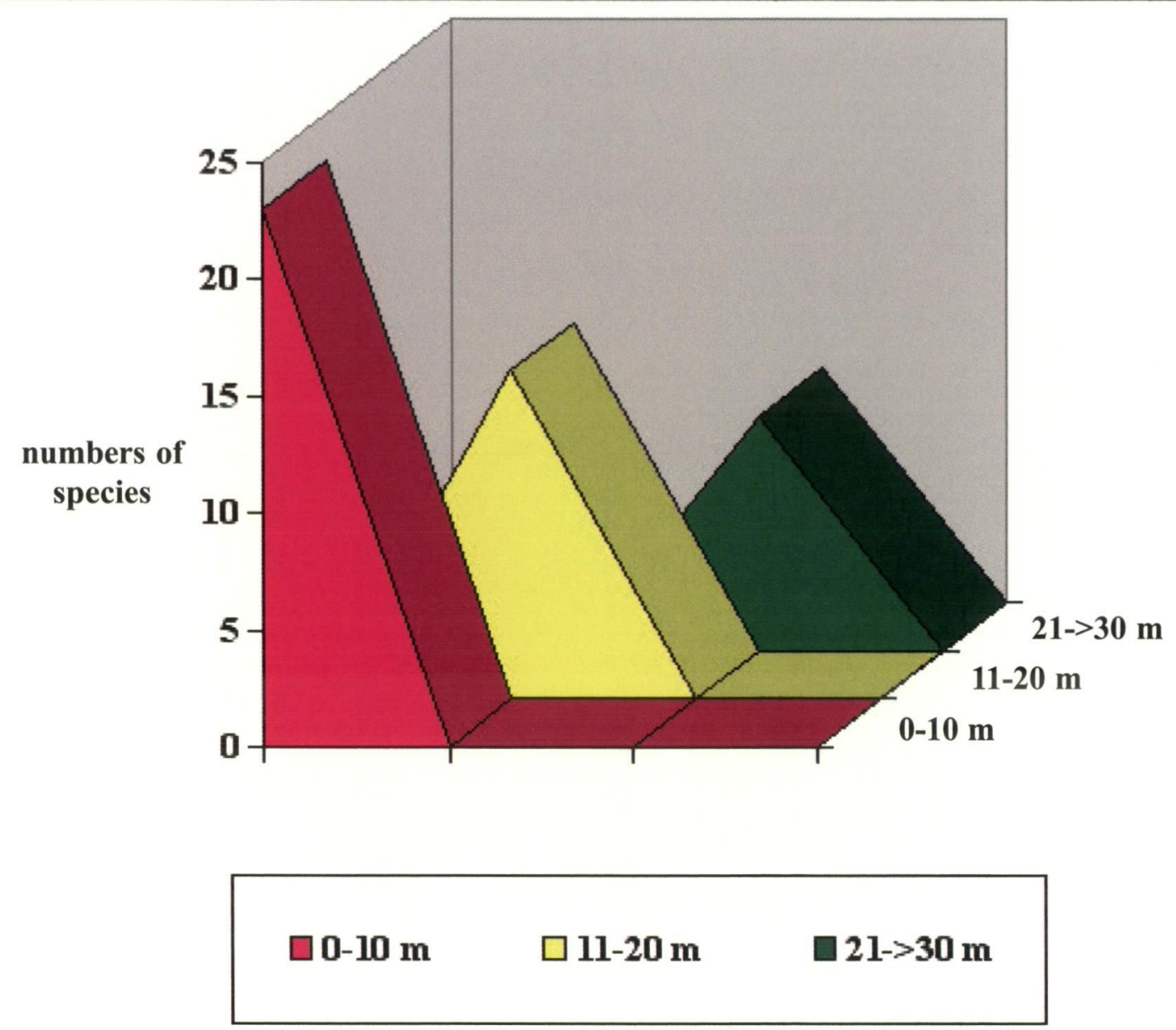


Table 15 Taxonomic and biogeographic affinities of the Dampier Archipelago cirripedes.

\begin{tabular}{|c|c|c|c|c|c|c|c|c|}
\hline \multicolumn{9}{|c|}{ Order PEDUNCULATA } \\
\hline Sub order & Family & Genus & Species & $\mathrm{C}$ & IWP & IA & $\mathbf{A A}$ & $\mathrm{AE}$ \\
\hline Iblomorpha & Iblidae & Ibla & cumingi & & + & & & \\
\hline \multirow{6}{*}{ Lepadomorpha } & Poecilasmatidae & Octolasmis & angulata & & & + & & \\
\hline & & Octolasmis & cf. bullata & & + & & & \\
\hline & & Temnaspis & excavatum & & + & & & \\
\hline & Lepadidae & Lepas & anserifera & + & & & & \\
\hline & & Lepas & pectinata & + & & & & \\
\hline & & Conchoderma & virgatum & + & & & & \\
\hline \multirow[t]{3}{*}{ Scalpellomorpha } & Calanticidae & Calantica & sp. nov. & & & & & + \\
\hline & Scalpellidae & Lithotrya & valentiana & & + & & & \\
\hline & \multicolumn{8}{|c|}{ Order SESSILIA } \\
\hline \multirow[t]{40}{*}{ Balanomorpha } & Chthamalidae & Caudceuraphia & cf. caudata & & & + & & \\
\hline & & Microeuraphia & sp. 1 & & & & & + \\
\hline & & Microeuraphia & sp. 2 & & & & & + \\
\hline & & Microeuraphia & withersi & & + & & & \\
\hline & & Chthamalus & malayensis & & + & & & \\
\hline & Coronulidae & Chelonibia & cf. caretta & & + & & & \\
\hline & & Chelonibia & patula & + & & & & \\
\hline & & Chelonibia & testudinaria & + & & & & \\
\hline & & Platylepas & decorata & & + & & & \\
\hline & & Platylepas & hexastylos & + & & & & \\
\hline & Tetraclitidae & Tetraclitella & multicostata & & & + & & \\
\hline & & Tetraclitella & sp. nov. & & & & & + \\
\hline & & Newmanella & vitiata & & + & & & \\
\hline & & Tetraclita & squamosa & & + & & & \\
\hline & Archaeobalanidae & Armatobalanus & arcuatus & & + & & & \\
\hline & & Armatobalanus & cf. cepa & & + & & & \\
\hline & & Armatobalanus & quadrivittatus & & + & & & \\
\hline & & Armatobalanus & terebratus & & & + & & \\
\hline & & Solidobalanus & ciliatus & & + & & & \\
\hline & & Striatobalanus & amaryllis & & + & & & \\
\hline & & Striatobalanus & bimae & & & + & & \\
\hline & & Striatobalanus & tenuis & & + & & & \\
\hline & & Conopea & calceolus & + & & & & \\
\hline & & Conopea & sp. 1 cf. navicula & & + & & & \\
\hline & & Conopea & sp. 2 cf. dentifer & & & + & & \\
\hline & & Conopea & spp & & + & & & \\
\hline & & Acasta & fenestrata & & + & & & \\
\hline & & Acasta & sulcata & & + & & & \\
\hline & & Acasta & spp & & + & & & \\
\hline & Pyrgomatidae & Savignium & dentatum & & + & & & \\
\hline & & Pyrgomatid & spp & & + & & & \\
\hline & Balanidae & Balanus & amphitrite & + & & & & \\
\hline & & Balanus & reticulatus & + & & & & \\
\hline & & Balanus & cirratus & & + & & & \\
\hline & & Balanus & trigonus & + & & & & \\
\hline & & Balanus & sp. nov. & & & & & + \\
\hline & & Megabalanus & ajax & & + & & & \\
\hline & & Megabalanus & cf. ajax & & + & & & \\
\hline & & Megabalanus & rosa & & & + & & \\
\hline & & Megabalanus & tintinnabulum & + & & & & \\
\hline Total 4 & 11 & 24 & 49 & 11 & 26 & 7 & 0 & 5 \\
\hline
\end{tabular}


Appendix 1 List of stations and associated barnacle species.

First Diving Expedition - DA1/98

DA1/98/01. - Dolphin I., 20²5.852'S, $116^{\circ} 52.953^{\prime} \mathrm{E} ; 3.0-$ $6.5 \mathrm{~m}$ : Acasta spp, Pyrgomatid spp.

DA1/98/02. - Dolphin I., 20²8.090'S, 116 $51.910^{\prime} \mathrm{E}$; intertidal: Ibla cumingi Darwin, Tetraclitella sp. nov., Nezmanella vitiata (Darwin), Balanus amphitrite Darwin, Balanus reticulatus Utinomi.

DA1/98/03. - Legendre I., 20²4.320'S, $116^{\circ} 56.108^{\prime} \mathrm{E} ; 2.0-$ $15.0 \mathrm{~m}$ : Acasta spp, Pyrgomatid spp, Megabalanus tintinnabulum (Linnaeus).

DA1/98/04. - Legendre I., 20²4.320'S, 116 $56.108^{\prime} \mathrm{E} ; 12.0$ $18.0 \mathrm{~m}$ : Pyrgomatid spp, Megabalanus tintinnabulum (Linnaeus).

DA1/98/06. - Haüy I., $20^{\circ} 25.725^{\prime}$ S, $116^{\circ} 57.580^{\prime} \mathrm{E}$; 0.5-2.0 $\mathrm{m}:$ Acasta spp.

DA1/98/07. - Gidley I., 20²8.010'S, $116^{\circ} 47.720^{\prime} \mathrm{E} ; 0.0-2.0$ $\mathrm{m}$ : Ibla cumingi Darwin, Chthamalus malayensis Pilsbry, Tetraclitella sp. nov., Tetraclita squamosa (Bruguière), Megabalanus tintinnabulum (Linnaeus).

DA1/98/08. - Angel I., 20²9.180'S, $116^{\circ} 47.711 ' \mathrm{E} ; 2.0-8.0$ $\mathrm{m}$ : Armatobalanus cf. cepa (Darwin), Acasta spp, Pyrgomatid spp, Balanus reticulatus Utinomi.

DA1/98/09. - Angel I., 20²8.692'S, $116^{\circ} 47.950^{\prime} \mathrm{E} ; 2.0-3.0$ $\mathrm{m}$ : Balanus reticulatus Utinomi, Balanus cirratus (Darwin).

DA1/98/10. - Angel I., $20^{\circ} 28.410^{\prime} S, 116^{\circ} 48.480^{\prime} \mathrm{E} ; 0.0-2.0$ $\mathrm{m}$ : Tetraclitella sp. nov., Newmanella vitiata (Darwin), Pyrgomatid spp, Balanus reticulatus Utinomi.

DA1/98/11. - Dolphin I., 20 30.249'S, 116 $49.335^{\prime} \mathrm{E}$; intertidal: Caudoeuraphia cf. caudata (Pilsbry), Chthamalus malayensis Pilsbry, Newmanella vitiata (Darwin), Tetraclita squamosa (Bruguière), Balanus amphitrite Darwin, Balanus reticulatus Utinomi, Balanus sp. nov.

DAl $/ 98 / 12$. - Angel I., $20^{\circ} 30.200^{\prime} \mathrm{S}, 116^{\circ} 47.250^{\prime} \mathrm{E} ; 2.0^{-7.0}$ $\mathrm{m}:$ Acasta spp.

DA1/98/13. - Hamersley Shoal, 20²3.203'S, 116 ${ }^{\circ} 46.691^{\prime} \mathrm{E}$; 1.0-16.0 m: Armatobalanus quadrivittatus (Darwin), Pyrgomatid spp.

DA1/98/14. - Unnamed I., 20²6.581'S, $116^{\circ} 48.790^{\prime} \mathrm{E}_{\text {; }}$ intertidal: Caudoeuraphia cf. caudata (Pilsbry), Megabalanus tintinnabulum (Linnaeus).

DA1/98/16. - Hamersley Shoal, 20²3.240'S, $116^{\circ} 47.080^{\prime} \mathrm{E}$; 2.0-4.0 m: Acasta spp, Megabalanus rosa (Pilsbry).

DA1/98/17. - Wilcox I., 20²7.090'S, 11650.438'E; intertidal: Striatobalanus amaryllis (Darwin), Conopea spp, Balanus reticulatus Utinomi, Megabalanus tintinnabulum (Linnaeus).

DA1/98/20. - Collier Rocks, $20^{\circ} 24.812^{\prime}$ 'S, $116^{\circ} 50.678^{\prime} \mathrm{E}$; intertidal: Acasta spp.

DA1/98/21. - Delambre I., $20^{\circ} 25.700^{\prime} \mathrm{S}, 117^{\circ} 04.220^{\prime} \mathrm{E} ; 2.0$ $19.0 \mathrm{~m}$ : Acasta spp.

DA1/98/23. - Dolphin I., 20²9.100'S, $116^{\circ} 52.220^{\prime} \mathrm{E}$; intertidal: Newmanella vitiata (Darwin).

DA1/98/24. - Dolphin I., 20²8.870'S, 11652.380'E; 2.0$7.0 \mathrm{~m}$ : Acasta spp, Megabalanus tintinnabulum (Linnaeus).

DA1/98/26. - Madeleine Shoal, 20¹9.343'S, 116 $50.455^{\prime} \mathrm{E}_{\text {; }}$ 15.0-30.0 m: Conopea spp.

DA1/98/27. - Legendre I., 20²4.044'S, 116 55.042'E; 1.0 $8.0 \mathrm{~m}$ : Ibla cumingi Darwin, Caudoeuraphia cf. caudata (Pilsbry), Chthamalus malayensis Pilsbry, Tetraclitella sp. nov., Tetraclita squamosa (Bruguière), Conopea spp, Balanus reticulatus Utinomi, Balanus cirratus (Darwin), Balanus sp. nov., Megabalanus rosa (Pilsbry), Megabalanus tintinnabulum (Linnaeus).
DA1/98/30. - Burrup Pen., 20³1.586'S, 116 $51.088^{\prime} \mathrm{E} ; 1.0$ $10.0 \mathrm{~m}$ : Armatobalanus cf. cepa (Darwin), Striatobalanus amaryllis (Darwin), Striatobalanus tenuis (Hoek), Acasta spp.

DA1/98/31. - Searipple Passage, 20³1.230'S, $116^{\circ} 51.182^{\prime} \mathrm{E}$; intertidal: Caudoeuraphia cf. caudata (Pilsbry), Tetraclita squamosa (Bruguière), Armatobalanus cf. cepa (Darwin), Balanus reticulatus Utinomi, Balanus sp. nov.

DA1/98/32. - Legendre I., 20²3.520'S, $116^{\circ} 54.110^{\prime} \mathrm{E} ; 5.0$ $17.0 \mathrm{~m}$ : Acasta spp.

DA1/98/33. - Angel I., 20²7.965'S, $116^{\circ} 49.692^{\prime} \mathrm{E} ; 1.0-8.0$ $\mathrm{m}$ : Armatobalanus quadrivittatus (Darwin), Striatobalanus amaryllis (Darwin), Conopea spp, Acasta spp, Pyrgomatid spp.

DA1/98/34. - Tozer I., 20²7.684'S, $116^{\circ} 50.486^{\prime} \mathrm{E}$; intertidal: Caudoeuraphia cf. caudata (Pilsbry).

DA1/98/35. - Legendre I., 20²3.620'S, $116^{\circ} 51.960^{\prime} \mathrm{E} ; 0.0$ $1.0 \mathrm{~m}$ : Newmanella vitiata (Darwin).

\section{Second Diving Expedition - DA3/99}

DA3/99/37. - NW Malus I., 20³0.050'S, 11640.594'E; 6.0-14.0 m: Acasta spp.

DA3/99/38. - N Malus I., 20³0.632'S, 116³8.788'E; intertidal: Newmanella vitiata (Darwin).

DA3/99/39. - NNE Brigadier I., 20²5.411'S, 116³7.578' $\mathrm{E}_{;}$ 15.0-27.0 m: Pyrgomatid spp, Megabalanus tintinnabulum (Linnaeus).

DA3/99/41. - Georges Reef, 20²9.339'S, 116 36.798'E; $1.0-4.0 \mathrm{~m}$ : Striatobalanus amaryllis (Darwin), Acasta spp.

DA3/99/42. - Georges Reef, 20²9.339'S, 116³6.798'E; intertidal: Tetraclitella sp. nov., Tetraclita squamosa (Bruguière), Megabalanus rosa (Pilsbry), Megabalanus tintinnabulum (Linnaeus).

DA3/99/45. - Rosemary I., E Tish Pt., 20²9.671'S, $116^{\circ} 35.894$ 'E; intertidal: Ibla cumingi Darwin, Chthamalus malayensis Pilsbry, Tetraclita squamosa (Bruguière).

DA3/99/48. - N Goodwyn I., 20³2.397'S, 116 32.606'E; intertidal: Lithotrya valentiana (Gray), Tetraclita squamosa (Bruguière).

DA3/99/49. - Goodwyn I., 20³2.397'S, $116^{\circ} 32.606^{\prime} \mathrm{E} ; 3.0-$ $9.0 \mathrm{~m}$ : Pyrgomatid spp.

DA3/99/50. - SE Bare Rock, 20³2.841'S, $116^{\circ} 26.733^{\prime} \mathrm{E}$; 10.0-20.0 m: Armatobalanus quadrivittatus (Darwin).

DA3/99/51. - $N$ end Enderby I., 20³5.196'S, $116^{\circ} 30.914 ' \mathrm{E}$; intertidal: Newmanella vitiata (Darwin), Tetraclita squamosa (Bruguière).

DA3/99/52. - NW Roly Rocks, 20²9.696'S, 116³0.166'E; 9.0-26.0 m: Conopea spp.

DA3/99/53. - Enderby I., $20^{\circ} 34.528^{\prime} \mathrm{S}, 116^{\circ} 34.575^{\prime} \mathrm{E} ; 3.0$ $7.0 \mathrm{~m}$ : Pyrgomatid spp.

DA3/99/54. - E Enderby I., 20³6.222'S, 116 33.063'E; intertidal: Caudoeuraphia cf. caudata (Pilsbry), Chthamalus malayensis Pilsbry, Tetraclitella sp. nov., Balanus amphitrite Darwin, Balanus sp. nov.

DA3/99/55. - Channel between Enderby I. and West Lewis I., $20^{\circ} 35.152$ 'S, $116^{\circ} 35.631^{\prime} \mathrm{E} ; 17.0 \mathrm{~m}$ : Striatobalanus amaryllis (Darwin), Conopea spp, Acasta spp, Pyrgomatid spp, Balanus sp. nov.

DA3/99/56. - Eaglehawk I., N of NW Point, 20³8.985'S, $116^{\circ} 26.210^{\prime} \mathrm{E} ; 2.0-11.0 \mathrm{~m}$ : Conopea spp, Balanus reticulatus Utinomi, Balanus cirratus (Darwin). 
DA3/99/57. - NNE North West Reefs, 20³7.702'S $116^{\circ} 25.089^{\prime} \mathrm{E} ; 11.0-13.0 \mathrm{~m}$ : Chthamalus malayensis Pilsbry, Tetraclitella sp. nov., Conopea spp.

DA3/99/59. - W Lewis I., 20³3.947'S, $116^{\circ} 38.334^{\prime} \mathrm{E}_{\text {; }}$ intertidal: Tetraclitella sp. nov., Tetraclita squamosa (Bruguière).

DA3/99/62. - SE Lewis I., 20³7.499'S, $116^{\circ} 39.182^{\prime} \mathrm{E}_{\text {; }}$ intertidal: Tetraclitella sp. nov., Balanus amphitrite Darwin.

DA3/99/63. - SW East Lewis I., 20³7.469'S, 116³8.246'E 0.0-5.0 m: Acasta spp.

DA3/99/65. - off Enderby I, SW of Rocky Head, 20³7.111'S, $116^{\circ} 26.780^{\prime} \mathrm{E}$; 13.0-15.0 m: Conopea spp, Acasta spp.

DA3/99/66. - S end, Enderby I., 20³6.700'S, $116^{\circ} 31.293$ 'E; intertidal: Ibla cumingi Darwin, Caudoeuraphia cf. caudata (Pilsbry), Chthamalus malayensis Pilsbry, Balanus sp. nov.

\section{Dredging Expedition - DA2/99}

DA2/99/04. - 4 n. miles NNW of Cohen I., 20 $19.64^{\prime} S$ $116^{\circ} 45.75^{\prime} \mathrm{E}$ to $20^{\circ} 19.82^{\prime} \mathrm{S}, 116^{\circ} 45.98^{\prime} \mathrm{E} ; 42.0-43.0 \mathrm{~m}$ : Conopea spp.

DA2/99/05. - 3.5 n. miles NE of C. Legendre, $20^{\circ} 19.79^{\prime} \mathrm{S}$, $116^{\circ} 53.85^{\prime} \mathrm{E}$ to $20^{\circ} 19.81^{\prime} \mathrm{S}, 116^{\circ} 53.39^{\prime} \mathrm{E} ; 38.0 \mathrm{~m}$ : Conopea calceolus (Ellis), Conopea spp.

DA2/99/06. - 2.7 n. miles ESE of C. Legendre, 20²1.69'S, $116^{\circ} 52.40^{\prime} \mathrm{E}$ to $20^{\circ} 21.23^{\prime} \mathrm{S}, 116^{\circ} 52.36^{\prime} \mathrm{E} ; 33.0-36.0 \mathrm{~m}$ Striatobalanus amaryllis (Darwin).

DA2/99/08. - 3.6 n. miles NNE of NW point of Delambre I., $20^{\circ} 22.76^{\prime} \mathrm{S}, 117^{\circ} 02.23^{\prime} \mathrm{E}$ to $20^{\circ} 23.12^{\prime} \mathrm{S}, 117^{\circ} 02.14^{\prime} \mathrm{E}$; 30.0-31.0 m: Striatobalanus amaryllis (Darwin).

DA2/99/09. - $5.5 \mathrm{n}$. miles $\mathrm{N}$ of NE corner of Delambre I., $20^{\circ} 20.38^{\prime} \mathrm{S}, 117^{\circ} 05.22^{\prime} \mathrm{E}$ to $20^{\circ} 20.68^{\prime} \mathrm{S}, 117^{\circ} 05.63^{\prime} \mathrm{E}$; 31.0-34.5 m: Striatobalanus amaryllis (Darwin), Conopea calceolus (Ellis).

DA2/99/10. - $1.9 \mathrm{n}$. miles $\mathrm{N}$ of NE point of Delambre I., $20^{\circ} 23.97^{\prime} \mathrm{S}, 117^{\circ} 04.82^{\prime} \mathrm{E}$ to $20^{\circ} 23.722^{\prime} \mathrm{S}, 117^{\circ} 04.70^{\prime} \mathrm{E} ; 29.0$ $\mathrm{m}$ : Striatobalanus amaryllis (Darwin), Acasta spp.

DA2/99/12. - $5.9 \mathrm{n}$. miles NNW of NW point of Delambre I., $20^{\circ} 20.75^{\prime} \mathrm{S}, 117^{\circ} 01.16^{\prime} \mathrm{E}$ to $20^{\circ} 20.19^{\prime} \mathrm{S}$, $117^{\circ} 01.18^{\prime} \mathrm{E} ; 32.0-34.0 \mathrm{~m}$ : Striatobalanus amaryllis (Darwin)

DA2/99/13. - 2.25 n. miles off Haüy I., 20²6.52'S, $117^{\circ} 00.50^{\prime} \mathrm{E}$ to $20^{\circ} 26.27^{\prime} \mathrm{S}, 117^{\circ} 00.56^{\prime} \mathrm{E} ; 19.5 \mathrm{~m}$ : Calantica sp. nov., Solidobalanus ciliatus (Hoek), Conopea calceolus (Ellis), Conopea spp, Pyrgomatid spp.

DA2 $/ 99 / 24 .-5.5$ n. miles $N$ of Lady Nora I., $20^{\circ} 21.79^{\prime} \mathrm{S}$ $116^{\circ} 38.05^{\prime} \mathrm{E}$ to $20^{\circ} 22.00^{\prime} \mathrm{S}, 116^{\circ} 37.81^{\prime} \mathrm{E} ; 38.5 \mathrm{~m}$ : Striatobalanus tenuis (Hoek)

DA2/99/29. - $4.35 \mathrm{n}$. miles $\mathrm{W}$ of C. Bruguieres, $20^{\circ} 24.64^{\prime} \mathrm{S}, 116^{\circ} 44.05^{\prime} \mathrm{E}$ to $20^{\circ} 24.76^{\prime} \mathrm{S}, 116^{\circ} 43.65^{\prime} \mathrm{E}$; 27.0-28.0 m: Striatobalanus amaryllis (Darwin), Conopea calceolus (Ellis).

DA2/99/33. - 3.3 n. miles NNE of Courtenay Head Light, Malus Is, $20^{\circ} 27.41^{\prime} \mathrm{S}, 116^{\circ} 42.57^{\prime} \mathrm{E}$ to $20^{\circ} 27.33^{\prime} \mathrm{S}$, $116^{\circ} 43.05^{\prime} \mathrm{E} ; 18.0-21.0 \mathrm{~m}$ : Striatobalanus amaryllis (Darwin), Striatobalanus bimae (Hoek), Conopea calceolus (Ellis) (dry), Acasta spp, Pyrgomatid spp.

DA2/99/34. - 3.3 n. miles NE of Courtenay Head Light, Malus Is, $20^{\circ} 32.65^{\prime} \mathrm{S}, 116^{\circ} 39.14^{\prime} \mathrm{E}$ to $20^{\circ} 32.72^{\prime} \mathrm{S}$, $116^{\circ} 39.59^{\prime} \mathrm{E} ; 9.0-13.0 \mathrm{~m}$ : Acasta spp.

DA2/99/35. - 1.9 n. miles W of High Point, on island NE of West Lewis I., $20^{\circ} 32.15^{\prime} \mathrm{S}, 116^{\circ} 38.86^{\prime} \mathrm{E}$ to $20^{\circ} 32.14^{\prime} \mathrm{S}, 116^{\circ} 38.16^{\prime} \mathrm{E} ; 13.0-15.0 \mathrm{~m}$ : Striatobalanus amaryllis (Darwin).
DA2/99/37. - 2.5 n. miles WNW of Marks Point, West Lewis I., $20^{\circ} 36.54^{\prime} \mathrm{S}, 116^{\circ} 34.98^{\prime} \mathrm{E}$ to $20^{\circ} 36.11^{\prime} \mathrm{S}$, $116^{\circ} 35.02 \mathrm{E} ; 14.0-15.0 \mathrm{~m}$ : Striatobalanus amaryllis (Darwin), Acasta spp.

DA2/99/40. -1.65 n. miles WSW of Bluff Point, Enderby I., $20^{\circ} 37.74^{\prime} \mathrm{S}, 116^{\circ} 31.05^{\prime} \mathrm{E}$ to $20^{\circ} 37.71^{\prime} \mathrm{S}, 116^{\circ} 31.57^{\prime} \mathrm{E}$; 10.5-11.0 m: Striatobalanus amaryllis (Darwin).

DA2/99/42. - 2.4 n. miles SW of SW point of Goodwyn I., $20^{\circ} 34.16^{\prime} \mathrm{S}, 116^{\circ} 30.11^{\prime} \mathrm{E}$ to $20^{\circ} 33.67^{\prime} \mathrm{S}, 116^{\circ} 30.01^{\prime} \mathrm{E}$; 14.0-16.0 m: Striatobalanus amaryllis (Darwin), Acasta $\mathrm{spp}$.

DA2/99/46. - 2.4 n. miles WNW of Rocky Head, Enderby I., $20^{\circ} 35.90^{\prime} \mathrm{S}, 116^{\circ} 25.60^{\prime} \mathrm{E}$ to $20^{\circ} 35.48^{\prime} \mathrm{S}$, $116^{\circ} 25.52^{\prime} \mathrm{E} ; 17.5-18.0 \mathrm{~m}$ : Striatobalanus amaryllis (Darwin).

DA2/99/47. - 3.9 n. miles just $\mathrm{N}$ of $\mathrm{W}$ of Rocky Head, Enderby I., $20^{\circ} 36.58^{\prime} \mathrm{S}, 116^{\circ} 23.66^{\prime} \mathrm{E}$ to $20^{\circ} 36.58^{\prime} \mathrm{S}$ $116^{\circ} 24.26^{\prime} \mathrm{E} ; 20.0-22.5 \mathrm{~m}$ : Striatobalanus amaryllis (Darwin).

DA2/99/49. - $3.3 \mathrm{n}$. miles just $\mathrm{S}$ of $\mathrm{W}$ of $\mathrm{W}$ point of Eaglehawk I., $20^{\circ} 40.30^{\prime} \mathrm{S}, 116^{\circ} 22.59^{\prime} \mathrm{E}$ to $20^{\circ} 39^{\prime} 81^{\prime} \mathrm{S}$, $116^{\circ} 22.60^{\prime} \mathrm{E}$; $15.5-16.0 \mathrm{~m}$ : Striatobalanus amaryllis (Darwin), Conopea calceolus (Ellis).

DA2/99/50. -6.5 n. miles W of Rocky Head, Enderby I., $20^{\circ} 37.10^{\prime} \mathrm{S}, 116^{\circ} 20.99^{\prime} \mathrm{E}$ to $20^{\circ} 37.28^{\prime} 5 \mathrm{~S}, 116^{\circ} 21.08^{\prime} \mathrm{E}$ 24.0-25.0 m: Striatobalanus amaryllis (Darwin), Acasta spp.

DA2/99/51. - 7.4 n. miles W of SW point of Goodwyn I., $20^{\circ} 32.40^{\prime} \mathrm{S}, 116^{\circ} 24.19^{\prime} \mathrm{E}$ to $20^{\circ} 32.59^{\prime} \mathrm{S}, 116^{\circ} 24.48^{\prime} \mathrm{E}$ 31.4-31.5 m: Striatobalanus amaryllis (Darwin).

DA2/99/56. - 2 n. miles W of Roly Rock, $20^{\circ} 30.10^{\prime}$ S, $116^{\circ} 28.27^{\prime} \mathrm{E}$ to $20^{\circ} 29.88^{\prime} \mathrm{S}, 116^{\circ} 27.93^{\prime} \mathrm{E} ; 33.0-34.5 \mathrm{~m}$ : Striatobalanus amaryllis (Darwin).

DA2/99/57. - 1.05 n. miles $N$ of Roly Rock, $20^{\circ} 29.03^{\prime} \mathrm{S}$ $116^{\circ} 30.45^{\prime} \mathrm{E}$ to $20^{\circ} 29.18^{\prime} \mathrm{S}, 116^{\circ} 30.06^{\prime} \mathrm{E} ; 32.0-33.0 \mathrm{~m}$ Armatobalanus arcuatus Hoek, Striatobalanus amaryllis (Darwin)

DA2/99/59. - 1.8 n. miles S of Courtenay Head Light, Malus Is, $20^{\circ} 32.23^{\prime} \mathrm{S}, 116^{\circ} 41.63^{\prime} \mathrm{E}$ to $20^{\circ} 32.09^{\prime} \mathrm{S}$, $116^{\circ} 41.16^{\prime} \mathrm{E} ; 17.0-19.0 \mathrm{~m}$ : Striatobalanus amaryllis (Darwin), Conopea calceolus (Ellis).

DA2/99/62. - Flying Foam Passage, 0.9 n. miles NE of S point of Angel I., $20^{\circ} 30.69^{\prime} \mathrm{S}, 116^{\circ} 48.58^{\prime} \mathrm{E}$ to $20^{\circ} 31.17^{\prime} \mathrm{S}, 116^{\circ} 48.33^{\prime} \mathrm{E} ; 7.0-9.0 \mathrm{~m}$ : Armatobalanus terebratus (Darwin), Striatobalanus amaryllis (Darwin), Conopea spp.

DA2/99/65. - 2.4 n. miles NW of light on East Intercourse I., $20^{\circ} 38.31^{\prime} \mathrm{S}, 116^{\circ} 38.46^{\prime} \mathrm{E}$ to $20^{\circ} 38.77 \mathrm{~S}$, $116^{\circ} 38.54^{\prime} \mathrm{E} ; 10.0-15.0 \mathrm{~m}$ : Armatobalanus terebratus (Darwin), Striatobalanus amaryllis (Darwin), Conopea calceolus (Ellis), Conopea sp. 1 cf. navicula (Darwin), Conopea sp. 2 cf. dentifer (Broch), Conopea spp, Acasta spp.

DA2/99/66. - 2.75 n. miles ESE of Bluff Point, Enderby I., $20^{\circ} 38.40^{\prime} \mathrm{S}, 116^{\circ} 35.66^{\prime} \mathrm{E}$ to $20^{\circ} 38.30^{\prime} \mathrm{S}, 116^{\circ} 36.01^{\prime} \mathrm{E}$ 7.2-7.5 m: Striatobalanus amaryllis (Darwin).

DA2/99/68. - 3.6 n. miles S of Bluff Point, Enderby I., $20^{\circ} 40.93^{\prime} \mathrm{S}, 116^{\circ} 33.21^{\prime} \mathrm{E}$ to $20^{\circ} 40.63^{\prime} \mathrm{S}, 116^{\circ} 33.36^{\prime} \mathrm{E}$; 9.0 $9.2 \mathrm{~m}$ : Conopea spp.

DA2/99/72. - 5.5 n. miles SSW of Rocky Head, Enderby I., $20^{\circ} 42.13^{\prime} \mathrm{S}, 116^{\circ} 26.22^{\prime} \mathrm{E}$ to $20^{\circ} 42.12^{\prime} \mathrm{S}, 116^{\circ} 26.52^{\prime} \mathrm{E}$. $10.0 \mathrm{~m}$ : Striatobalanus amaryllis (Darwin).

DA2/99/73. - 3.25 n. miles S of Rocky Head, Enderby I. $20^{\circ} 40.14^{\prime} \mathrm{S}, 116^{\circ} 27.69^{\prime} \mathrm{E}$ to $20^{\circ} 39.93^{\prime} \mathrm{S}, 116^{\circ} 27.96^{\prime} \mathrm{E} ; 12.5$ $\mathrm{m}$ : Striatobalanus amaryllis (Darwin).

DA2/99/74. - 1.95 n. miles SE of Rocky Head, Enderby I., $20^{\circ} 38.34^{\prime} \mathrm{S}, 116^{\circ} 29.18^{\prime} \mathrm{E}$ to $20^{\circ} 38.83^{\prime} \mathrm{S}, 116^{\circ} 28.85$ 
10.5-11.5 m: Striatobalanus amaryllis (Darwin), Conopea calceolus (Ellis), Conopea spp.

DA2/99/75. - 0.75 n. miles E of NE point of Goodwyn I., $20^{\circ} 32.16^{\prime} \mathrm{S}, 116^{\circ} 33.70^{\prime} \mathrm{E}$ to $20^{\circ} 31.70^{\prime} \mathrm{S}, 116^{\circ} 33.20^{\prime} \mathrm{E}$; 14.0-19.0 m: Striatobalanus amaryllis (Darwin), Conopea calceolus (Ellis), Conopea spp, Acasta spp.

DA2/99/76. $-0.4 \mathrm{n}$. miles $\mathrm{W}$ of NW point of Goodwyn I., $20^{\circ} 32.11 \mathrm{~S}, 116^{\circ} 31.55^{\prime} \mathrm{E}$ to $20^{\circ} 32.40^{\prime} \mathrm{S}, 116^{\circ} 31.22^{\prime} \mathrm{E}$; 13.0-15.0 m: Striatobalanus amaryllis (Darwin).

DA2/99/82. $-1.2 \mathrm{n}$. miles $\mathrm{N}$ of $\mathrm{N}$ point of Kendrew I., $20^{\circ} 27.57^{\prime} \mathrm{S}, 116^{\circ} 32.35^{\prime} \mathrm{E}$ to $20^{\circ} 27.18^{\prime} \mathrm{S}, 116^{\circ} 32.29^{\prime} \mathrm{E}$ 32.0-36.0 m: Striatobalanus amaryllis (Darwin).

DA2/99/83. - $3.15 \mathrm{n}$. miles ENE of NE point of Goodwyn I., $20^{\circ} 31.60^{\prime} \mathrm{S}, 116^{\circ} 36.19^{\prime} \mathrm{E}$ to $20^{\circ} 31.37^{\prime} \mathrm{S}, 116^{\circ} 35.76^{\prime} \mathrm{E}$; 11.5-11.7 m: Striatobalanus amaryllis (Darwin).

DA2/99/84. $-2.9 \mathrm{n}$. miles E of Tish Point, Rosemary I., $20^{\circ} 29.94^{\prime} \mathrm{S}, 116^{\circ} 38.11^{\prime} \mathrm{E}$ to $20^{\circ} 29.84^{\prime} \mathrm{S}, 116^{\circ} 38.64^{\prime} \mathrm{E}$ 12.5-15.0 m: Solidobalanus ciliatus (Hoek), Acasta spp.

DA2/99/88. - $0.7 \mathrm{n}$. miles $\mathrm{N}$ of $\mathrm{W}$ of Brigadier I. $20^{\circ} 26.04^{\prime} \mathrm{S}, 116^{\circ} 36.77^{\prime} \mathrm{E}$ to $20^{\circ} 25.63^{\prime} \mathrm{S}, 116^{\circ} 36.85^{\prime} \mathrm{E}$; $33.5-38.5 \mathrm{~m}$ : Acasta spp.

DA2/99/90. - 3.5 n. miles N of Gordon Point, Rosemary I., $20^{\circ} 25.68^{\prime} \mathrm{S}, 116^{\circ} 33.96^{\prime} \mathrm{E}$ to $20^{\circ} 25.62^{\prime} \mathrm{S}, 116^{\circ} 34.38^{\prime} \mathrm{E}$; $38.0 \mathrm{~m}$ : Armatobalanus quadrivittatus (Darwin).

DA2/99/94. - 0.6 n. miles SE of King Point, East Lewis I., $20^{\circ} 38.37^{\prime} \mathrm{S}, 116^{\circ} 38.41^{\prime} \mathrm{E}$ to $20^{\circ} 38.39^{\prime} \mathrm{S}, 116^{\circ} 38.52^{\prime} \mathrm{E}$; $14.5-16.0 \mathrm{~m}$ : Striatobalanus amaryllis (Darwin), Conopea calceolus (Ellis).

DA2/99/96. - 1.3 n. miles $W$ of Bluff Point, Enderby I., $20^{\circ} 37.50^{\prime} \mathrm{S}, 116^{\circ} 31.56^{\prime} \mathrm{E}$ to $20^{\circ} 37.57^{\prime} \mathrm{S}, 116^{\circ} 31.61^{\prime} \mathrm{E} ; 9.0$ $\mathrm{m}$ : Striatobalanus amaryllis (Darwin).

DA2/99/99. - 1.05 n. miles WSW of Rocky Head, Enderby I., $20^{\circ} 37.36^{\prime} \mathrm{S}, 116^{\circ} 26.85^{\prime} \mathrm{E}$ to $20^{\circ} 37.02^{\prime} \mathrm{S}$, $116^{\circ} 26.44^{\prime} \mathrm{E} ; 17.0-19.0 \mathrm{~m}$ : Solidobalanus ciliatus (Hoek), Acasta spp.

\section{Additional Shore Collection Localities}

Burrup Peninsula

Cowrie Cove: Ibla cumingi Darwin, Tetraclitella sp. nov., Tetraclita squamosa (Bruguière), Balanus amphitrite Darwin, Balanus sp. nov.

Searipple Passage: Newmanella vitiata (Darwin).

Watering Cove: Ibla cumingi Darwin, Octolasmis cf. bullata (Aurivillius), Caudoeuraphia cf. caudata (Pilsbry), Microeuraphia withersi (Pilsbry), Chthamalus malayensis Pilsbry, Chelonibia patula (Ranzani), Chelonibia cf. caretta (Spengler), Tetraclitella sp. nov., Newmanella vitiata (Darwin), Tetraclita squamosa (Bruguière), Armatobalanus quadrivittatus (Darwin), Acasta spp, Balanus amphitrite Darwin, Balanus reticulatus Utinomi, Balanus cirratus (Darwin), Balanus sp. nov., Megabalanus cf. ajax (Darwin).

Withnell Bay: Caudoeuraphia cf. caudata (Pilsbry), Microeuraphia withersi (Pilsbry), Chthamalus malayensis Pilsbry, Tetraclita squamosa (Bruguière), Balanus amphitrite Darwin, Balanus reticulatus Utinomi, Balanus cirratus (Darwin), Balanus sp. nov.

Mainland

Cape Preston: Chthamalus malayensis Pilsbry, Chelonibia patula (Ranzani), Tetraclitella sp. nov., Tetraclita squamosa (Bruguière), Balanus reticulatus Utinomi, Balanus cirratus (Darwin).

Dampier Beach: Caudoeuraphia cf. caudata (Pilsbry), Microeuraphia sp. 1, Microeuraphia sp. 2, Chthamalus malayensis Pilsbry, Tetraclitella sp. nov., Newmanella vitiata (Darwin), Balanus amphitrite Darwin, Balanus cirratus (Darwin).

Dampier Salt Beach: Newmanella vitiata (Darwin), Balanus amphitrite Darwin, Balanus cirratus (Darwin).

Point Cleaverville: Caudoeuraphia cf. caudata (Pilsbry), Chthamalus malayensis Pilsbry, Tetraclitella sp. nov., Newmanella vitiata (Darwin), Tetraclita squamosa (Bruguière), Balanus amphitrite Darwin, Balanus reticulatus Utinomi, Balanus cirratus (Darwin), Balanus sp. nov. 
Appendix 2 Checklist of the barnacles of the shallow waters of the Dampier Archipelago.

Class Maxillopoda Dahl, 1956

Subclass Cirripedia Burmeister, 1834

Superorder Thoracica Darwin, 1854

Order Pedunculata Lamarck, 1818

Suborder Iblomorpha Newman, 1987

Family Iblidae Leach, 1825

Genus Ibla Leach, 1825

Ibla cumingi Darwin, 1851: 183

Woodside Collections:

Burrup Peninsula/Mainland

Burrup Peninsula Watering Cove

Burrup Peninsula Cowrie Cove

WAM C 24991, C 28122

WAM C 24992

\section{DA1 First Diving Expedition}

\begin{tabular}{|c|c|c|}
\hline Dampier Archipelago & Dolphin I. & $\mathrm{DA}$ \\
\hline Dampier Archipelago & Gidley I. & \\
\hline Dampier Archipelago & Legendre I. & \\
\hline \multicolumn{3}{|c|}{ DA3 Second Diving Expedition } \\
\hline Dampier Archipelago & Rosemary I., E Tish Pt & \\
\hline Dampier Archipelago & S end, Enderby I. & \\
\hline \multicolumn{3}{|c|}{ Additional Museum Collection Data: } \\
\hline Dampier Archipelago & \multirow{4}{*}{\multicolumn{2}{|c|}{$\begin{array}{l}\text { Citadel Rock, Kendrew I. } \\
\text { N of Withnell Bay, } 20^{\circ} 28^{\prime} \mathrm{S} 116^{\circ} 32^{\prime} \mathrm{E} \\
\text { Near Roebourne } \\
\text { Depuch I. }\end{array}$}} \\
\hline Burrup Peninsula & & \\
\hline Mainland & & \\
\hline Mainland & & \\
\hline
\end{tabular}

WAM C 27404

WAM C 27405, C 29422

WAM C 16373 to C 16378

WAM C 16379, C 16380

WAM C 16382

WAM C 16381, C 23712

Suborder Lepadomorpha Pilsbry, 1916

Family Poecilasmatidae Annandale, 1909 Genus Octolasmis Gray, 1825

Octolasmis angulata (Aurivillius, 1894: 22)

(=O. aperta Aurivillius, 1894: 24)

Additional Museum Collection Data:

Dampier Archipelago Enderby I.; attached to gills of

Panulirus versicolor

WAM C 23177

Octolasmis cf. bullata (Aurivillius, 1892: 125)

Woodside Collections:

Burrup Peninsula/Mainland

Burrup Peninsula Watering Cove; attached to gills of Portunus pelagicus (Linnaeus, 1758)

WAM C 24993, C 27302, C 27304, C 27305, C 27395

Genus Temnaspis Linnaeus, 1758

Temnaspis excavatum (Hoek, 1907: 10)

Additional Museum Collection Data:

Dampier Archipelago

Roly Rock; attached to gills of Panulirus versicolor

WAM C 29399

Family Lepadidae Darwin, 1851

Genus Lepas Linnaeus, 1758

Subgenus Anatifa Bruguière, 1789

Lepas (Anatifa) anserifera Linnaeus 1767: 1109

Additional Museum Collection Data:

Off Dampier Archipelago North Rankin Oil Platform

WAM C 23875 
Lepas (Anatifa) pectinata Spengler, 1793: 106

Additional Museum Collection Data:

Dampier Archipelago Kendrew I.

Dampier Archipelago Enderby I.

Genus Conchoderma Olfers, 1814

Conchoderma virgatum (Spengler, 1790: 207)

Additional Museum Collection Data:

Off Dampier Archipelago North Rankin oil platform

WAM C.14431, C 23703
Suborder Scalpellomorpha Newman, 1987
Family Calanticidae Zevina, 1978a
Genus Calantica Gray, 1825

Calantica sp. nov.

Woodside Collections:

DA2 Dredging Expedition

Dampier Archipelago 2.25 n. miles off Haüy I. DA2/99/13 WAM C 28197

Family Lithotryidae Gruvel, 1905

Genus Lithotrya Sowerby, 1922

Lithotrya valentiana (Gray, 1825: 102)

Woodside Collections:

DA3 Second Diving Expedition

Dampier Archipelago N Goodwyn I

DA3/99/48

WAM C 27428

Additional Museum Collection Data:

Dampier Archipelago

Dampier Archipelago

Dampier Archipelago

Dampier Archipelago

Dampier Archipelago

Mainland

$20^{\circ} 33^{\prime} \mathrm{S} 116^{\circ} 32^{\prime} \mathrm{E}$

No other data

Kendrew I.

Kendrew I.

Enderby 1 .

Karratha
AM P 40920 (as Lithotrya dorsalis)

WAM C 29400

AM P 40888

WAM C $11610, C 11611, C 16303$ to

C 16323; C 21262, C 23707

WAM C 21260

WAM C 21261

Order Sessilia

Suborder Balanomorpha Pilsbry, 1916

Superfamily Chthamaloidea Darwin, 1854

Family Chthamalidae Darwin, 1854

Subfamily Euraphiinae Newman and Ross, 1976

Genus Caudoeuraphia Poltarukha, 1997

Caudoeuraphia cf. caudata (Pilsbry, 1916: 315)

Woodside Collections:

Burrup Peninsula/Mainland

Burrup Peninsula

Burrup Peninsula

Mainland

Mainland
Withnell Bay

Watering Cove

Dampier, Front Beach

Point Cleaverville
WAM C 27261 to C 27269

WAM C 27275 to $C 27277$

WAM C 27273, C 27274

WAM C 27259, C 27260

\section{DA1 First Diving Expedition}

$\begin{array}{llll}\text { Dampier Archipelago } & \text { Dolphin I. } & \text { DA1 } / 98 / 11 & \text { WAM C 27247 } \\ \text { Dampier Archipelago } & \text { Unnamed I. } & \text { DA1/98/14 } & \text { WAM C 27248 } \\ \text { Dampier Archipelago } & \text { Legendre I. } & \text { DA1 } / 98 / 27 & \text { WAM C 27257 } \\ \text { Dampier Archipelago } & \text { Searipple Passage } & \text { DAI } / 98 / 31 & \text { WAM C 27243 } \\ \text { Dampier Archipelago } & \text { Tozer I. } & \text { DA1 } / 98 / 34 & \text { WAM C 27246 }\end{array}$


DA3 Second Diving Expedition
Dampier Archipelago
E Enderby I.
DA3 $/ 99 / 54$
WAM C 27419
Dampier Archipelago
S Enderby I.
DA3/99/66
WAM C 27429

Genus Microeuraphia Poltarukha, 1997

Microeuraphia withersi (Pilsbry, 1916: 312)

Woodside Collections:

Burrup Peninsula/Mainland

Burrup Peninsula Watering Cove

WAM C 29409

Burrup Peninsula

Withnell Bay

WAM C 29406

Additional Museum Collection Data:

Dampier Archipelago Enderby I.

WAM C 21221

Mainland

Dampier

WAM C 21219

Microeuraphia sp. 1

Woodside Collections:

Burrup Peninsula/Mainland

Mainland

Dampier, Front Beach

WAM C 27271, C 27272

Microeuraphia sp. 2

Woodside Collections:

Burrup Peninsula/Mainland

Mainland

Dampier, Front Beach

WAM C 27270

Subfamily: Chthamalinae Darwin, 1854

Genus Chthamalus Ranzani, 1817

Chthamalus malayensis Pilsbry 1916: 310

Woodside Collections:

Burrup Peninsula/Mainland

Burrup Peninsula Withnell Bay

Burrup Peninsula Watering Cove

Burrup Peninsula Rocks N of Watering Cove

Mainland

Cape Preston

Dampier Beach

Point Cleaverville

Mainland

NE Point Cleaverville

WAM C 27265, C 27285 to C 27287

WAM C 27278 to C 27283

WAM C 27284

WAM C 27291

WAM C 27290

WAM C 27288

Mainland

WAM C 27289

DA1 First Diving Expedition

Dampier Archipelago

Gidley I.

DA1/98/07

WAM C 27258

Dampier Archipelago

Dolphin I.

DA1/98/11

Legendre I.

DA1 $/ 98 / 27$

WAM C 25739, C 27256

WAM C 27257

DA3 Second Diving Expedition

Dampier Archipelago

Dampier Archipelago

Dampier Archipelago

Dampier Archipelago

Dampier Archipelago
Rosemary I., E Tish Pt.

E Enderby I.

NNE North West Reefs

DA3/99/45

DA3/99/54

DA3/99/57

DA3/99/59

DA3/99/66

S Enderby I.
WAM C 27417

WAM C 27419

WAM C 27418

WAM C 29419

WAM C 27416, C 29417

Additional Museum Collection Data:

Dampier Archipelago Dampier Archipelago Dampier Archipelago Dampier Archipelago Mainland
Dolphin I., SW corner

Kendrew I.

Enderby I.

East Lewis I.

Hamersley Iron intake pipe, Dampier
WAM C 23700

WAM C 21224

WAM C 21226, C 21227, C 29417

WAM C 21223

WAM C 29414 
Superfamily Coronuloidea Leach, 1817

Family Chelonibiidae Pilsbry, 1916

Genus Chelonibia Leach, 1817

Chelonibia cf. caretta (Spengler, 1790: 185)

Woodside Collections:

Burrup Peninsula/Mainland

Dampier Archipelago Watering Cove; attached to carapace of Eretmochelys imbricata (Borradaile)

Additional Museum Collection Data:

Dampier Archipelago Dolphin I.; attached to carapace of Eretmochelys WAM C 13898, C 13899 imbricata (Borradaile)

Chelonibia patula (Ranzani, 1818: 86)

Woodside Collections:

Burrup Peninsula/Mainland

Dampier Archipelago Watering Cove; attached to carapace of Portunus pelagicus (Linnaeus, 1758)

Mainland

Cape Preston

Additional Museum Collection Data:

Mainland

Nickol Bay, near Roebourne

AM P 21899

Chelonibia testudinaria (Linnaeus, 1758: 668)

Additional Museum Collection Data:

Burrup Peninsula No locality data; attached to carapace of

Eretmochelys imbricata (Borradaile)

WAM C 19997

Family Platylepadidae Newman and Ross, 1976

Genus Platylepas Gray, 1825

Platylepas decorata Darwin, 1854: 429

Additional Museum Collection Data:

Burrup Peninsula No locality data; attached to carapace of

Eretmochelys imbricata (Borradaile)

WAM C 20004

Platylepas hexastylos (Fabricius, 1798: 35)

Additional Museum Collection Data:

Mainland

Karratha, Nickol Bay; attached to Dugong dugon WAM C 18949 (Müller, 1776)

Superfamily Tetraclitoidea Gruvel, stat. nov. (Newman, 1993)

Family Tetraclitidae Gruvel, 1903

Subfamily Tetraclitellinae Newman and Ross, 1976

Genus Tetraclitella Hiro, 1939

Tetraclitella multicostata (Nilsson-Cantell, 1930a: 2)

Additional Museum Collection Data:

Dampier Archipelago Boat Passage

Dampier Archipelago Enderby I.

Dampier Archipelago East Lewis I
WAM C 16427

WAM C 21235, C 21236, C 21238, C 21240

WAM C 21237

Tetraclitella sp. nov.

Woodside Collections:

Burrup Peninsula/Mainland

Burrup Peninsula Watering Cove

WAM C 27309 to C 27311, C 27313,

C 27314, C 29412, C 29413 
Burrup Peninsula

Burrup Peninsula

Mainland

Mainland

Mainland
Rocks $\mathrm{N}$ of Watering Cove

Cowrie Cove

Cape Preston

Dampier Beach

Point Cleaverville
WAM C 27308

WAM C 27317, C 27318

WAM C 27319

WAM C 27320

WAM C 27315, C 27316

DA1 First Diving Expedition

$\begin{array}{llll}\text { Dampier Archipelago } & \text { Dolphin I. } & \text { DA1/98/02 } & \text { WAM C 27252 } \\ \text { Dampier Archipelago } & \text { Gidley I. } & \text { DA1/98/07 } & \text { WAM C 25754 } \\ \text { Dampier Archipelago } & \text { Angel I. } & \text { DA1/98/10 } & \text { WAM C 27242 } \\ \text { Dampier Archipelago } & \text { Lègendre I. } & \text { DA1 } 1 / 98 / 27 & \text { WAM C 27426 }\end{array}$

DA3 Second Diving Expedition

$\begin{array}{llll}\text { Dampier Archipelago } & \text { Georges Reef } & \text { DA3/99/42 } & \text { WAM C 27295 } \\ \text { Dampier Archipelago } & \text { E Enderby I. } & \text { DA3/99/54 } & \text { WAM C 27411 } \\ \text { Dampier Archipelago } & \text { North West Reefs } & \text { DA3/99/57 } & \text { WAM C 27413 } \\ \text { Dampier Archipelago } & \text { W Lewis I. } & \text { DA3/99/59 } & \text { WAM C 27415 } \\ \text { Dampier Archipelago } & \text { SE Lewis I. } & \text { DA3/99/62 } & \text { WAM C 27412 }\end{array}$

Additional Museum Collection Data:

Dampier Archipelago Gidley I.

WAM C 7558

Genus Newmanella Ross, 1969

Newmanella vitiata (Darwin, 1854: 340)

Woodside Collections:

Burrup Peninsula/Mainland

Burrup Peninsula

Burrup Peninsula

Burrup Peninsula

Mainland

Mainland
Watering Cove

Sea Ripple Passage

Dampier Salt Beach

Point Cleaverville
Dampier Beach

WAM C 27299, C 27301

WAM C 27296, C 27297, C 27302, C 29411

WAM C 27300

WAM C 27345

WAM C 27298, C 29424

WAM C 27245

WAM C 25737

WAM C 25722

WAM C 25746

WAM C 25724

Legendre I.

DA1 $/ 98 / 35$

$\mathrm{DA} 3 / 99 / 38$

$\mathrm{DA} 3 / 99 / 51$

WAM C 27424

WAM C 27425

WAM C 21249, C 21251, C 21252

WAM C 21253

WAM C 21250

Genus Tetraclita Schumacher, 1817

Tetraclita squamosa (Bruguière, 1789: 170)

Woodside Collections:

Burrup Peninsula/Mainland

Burrup Peninsula

Burrup Peninsula

Burrup Peninsula

Burrup Peninsula

Mainland

Mainland

Watering Cove
Rocks N of Watering Cove
Cowrie Cove
Withnell Bay
Cape Preston
Point Cleaverville

Watering Cove

Cowrie Cove

Point Cleaverville
WAM C 27328, C 27329, C 27331

WAM C 27330

WAM C 27327

WAM C 27332

WAM C 27333

WAM C 27357

DA1 First Diving Expedition

$\begin{array}{llll}\text { Dampier Archipelago } & \text { Gidley I. } & \text { DA1 } / 98 / 07 & \text { WAM C 27249 } \\ \text { Dampier Archipelago } & \text { Dolphin I. } & \text { DA1 } / 98 / 11 & \text { WAM C 27251 }\end{array}$


Dampier Archipelago

Dampier Archipelago

Legendre I.

Searipple Passage

DA1 $/ 98 / 27$

DA1 $/ 98 / 31$

DA3/99/42

DA3 $/ 99 / 45$

DA3 $/ 99 / 48$

DA3 $/ 99 / 51$

DA3/99/59

Dampier Archipelago

Dampier Archipelago
Georges Reef

Rosemary I., E Tish Pt.

N Goodwyn I.

. 1 .

W Lewis I.
WAM C 27250

WAM C 27260

\author{
WAM C 27294 \\ WAM C 27420, C 27423 \\ WAM C 27422 \\ WAM C 27421 \\ WAM C 27414
}

Additional Museum Collection Data:

Dampier Archipelago

Dampier Archipelago

Dampier Archipelago

No other data

Beacon (no other data)

Kendrew I.

Citadel Rock, Kendrew I.

$\mathrm{N}$ side of Kendrew I.

NW side of Kendrew I.

Dampier Archipelago

Dampier Archipelago

Dampier Archipelago

Dampier Archipelago

Dampier Archipelago

Dampier Archipelago

Burrup Peninsula
Boat Passage

Enderby I.

East Lewis I.

Beacon I.

No other data

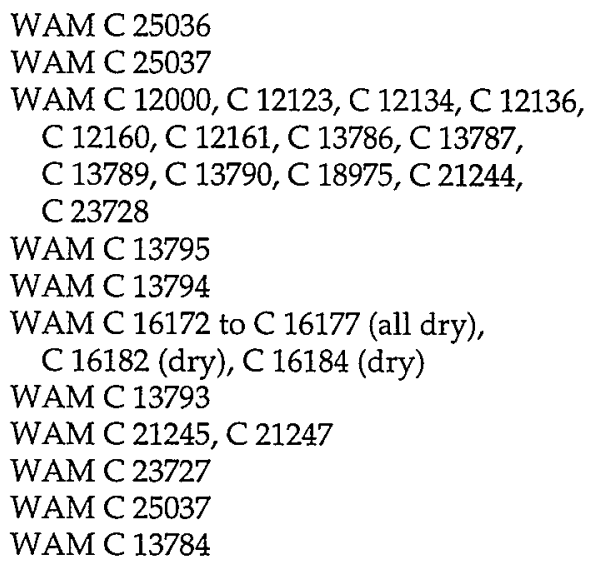

Superfamily Balanoidea Leach, 1817

Family Archaeobalanidae Newman and Ross, 1976

Subfamily Archaeobalaninae Newman and Ross, 1976

Genus Armatobalanus Hoek, 1913

Armatobalanus arcuatus Hoek, 1913

Woodside Collections:

DA2 Dredging Expedition

Dampier Archipelago Roly Rock

DA2/99/57

WAM C 28167 (dry)

Armatobalanus cf. cepa (Darwin, 1854: 283)

Woodside Collections:

DA1 First Diving Expedition

$\begin{array}{llll}\text { Dampier Archipelago } & \text { Angel I. } & \text { DA1 } / 98 / 08 & \text { WAM C 25736 } \\ \text { Burrup Peninsula } & 20^{\circ} 31.5866^{\prime} \text { S, 116 } 51.088^{\prime} \mathrm{E} & \text { DAI } / 98 / 30 & \text { WAM C 27232 } \\ \text { Dampier Archipelago } & \text { Searipple Passage } & \text { DA1 } / 98 / 31 & \text { WAM C 25753 }\end{array}$

Armatobalanus quadrivittatus (Darwin, 1854: 284)

Woodside Collections:

Burrup Peninsula/Mainland

Burrup Peninsula Watering Cove, attached to Acanthopleura spinosa (Bruguière, 1792)

WAM C 29408

DA1 First Diving Expedition

Dampier Archipelago Hamersley Shoal DA1 $\quad$ W $\quad$ WAM C 25723

Dampier Archipelago Angel I. DA1 $\quad$ W $\quad$ WAM C 25730

DA2 Dredging Expedition

Dampier Archipelago Rosemary I.

DA2/99/90

WAM C 28172

DA3 Second Diving Expedition

$\begin{array}{lll}\text { Dampier Archipelago } & \text { SE Bare Rock } & \text { DA3/99/50 WAM C 27397 }\end{array}$ 
Additional Museum Collection Data:

Dampier Archipelago Roly Rock

WAM C 21229

Dampier Archipelago

Kendrew I.

WAM C 29418

Armatobalanus terebratus (Darwin, 1854: 285)

Woodside Collections:

DA2 Dredging Expedition

Dampier Archipelago E Intercourse I.

DA2/99/65

WAM C 28171

Genus Solidobalanus Hoek, 1913

Solidobalanus ciliatus (Hoek, 1913: 199)

Woodside Collections:

DA2 Dredging Expedition

Dampier Archipelago

Haüy I.

DA2/99/13

WAM C 28168

Dampier Archipelago

Rosemary I.

$\mathrm{DA} 2 / 99 / 84$

WAM C 28169

Dampier Archipelago

Enderby I.

DA2/99/99

WAM C 28170

Additional Museum Collection Data:

Dampier Archipelago

Goodwin I.

WAM C 28316

Dampier Archipelago

Roly Rock

WAM C 28315

Dampier Archipelago

Rosemary I.

AM P 40921

Dampier Archipelago

$50 \mathrm{n}$ mls WNW Rosemary I.

WAM C 17765

Genus Striatobalanus Hoek, 1913

Striatobalanus amaryllis (Darwin, 1854: 279)

Woodside Collections:

DA1 First Diving Expedition

\begin{tabular}{|c|c|c|c|}
\hline Dampier Archipelago & Dolphin I. & DA1/98/02 & WAM C 29404 \\
\hline Dampier Archipelago & Wilcox I. & $\mathrm{DA} 1 / 98 / 17$ & WAM C 27231 \\
\hline Burrup Peninsula & $20^{\circ} 31.586^{\prime} \mathrm{S}, 116^{\circ} 51.088^{\prime} \mathrm{E}$ & $\mathrm{DAI} / 98 / 30$ & WAM C 27235 \\
\hline Dampier Archipelago & Angel I. & DA1/98/33 & WAM C 25731 \\
\hline \multicolumn{4}{|c|}{ DA2 Dredging Expedition } \\
\hline Dampier Archipelago & $\begin{array}{l}2.7 \mathrm{n} \text {. miles ESE of Cape } \\
\text { Legendre }\end{array}$ & $\mathrm{DA} 2 / 99 / 06$ & WAM C 28195 \\
\hline Dampier Archipelago & $\begin{array}{l}3.6 \mathrm{n} \text {. miles NNE of NW } \\
\text { point of Delambre I. }\end{array}$ & DA2/99/08 & WAM C 28194 \\
\hline Dampier Archipelago & $\begin{array}{l}5.5 \mathrm{n} \text {. miles } \mathrm{N} \text { of } \mathrm{NE} \text { corner } \\
\text { of Delambre I. }\end{array}$ & DA2/99/09 & WAM C 28192 \\
\hline Dampier Archipelago & $\begin{array}{l}1.9 \mathrm{n} \text {. miles } \mathrm{N} \text { of } \mathrm{NE} \text { point } \\
\text { of Delambre I. }\end{array}$ & $\mathrm{DA} 2 / 99 / 10$ & WAM C 28193 \\
\hline Dampier Archipelago & $\begin{array}{l}5.9 \mathrm{n} \text {. miles NNW of NW } \\
\text { point of Delambre I. }\end{array}$ & DA2/99/12 & WAM C 28191 \\
\hline Dampier Archipelago & $\begin{array}{l}4.35 \mathrm{n} \text {. miles } \mathrm{W} \text { of Cape } \\
\text { Bruguieres }\end{array}$ & $\mathrm{DA} 2 / 99 / 29$ & WAM C 28190 \\
\hline Dampier Archipelago & $\begin{array}{l}3.3 \text { n. miles NNE of } \\
\text { Courtenay Head Light, } \\
\text { Malus I. }\end{array}$ & $\mathrm{DA} 2 / 99 / 33$ & WAM C 28189 \\
\hline Dampier Archipelago & $\begin{array}{l}1.9 \mathrm{n} \text {. miles } \mathrm{W} \text { of High } \\
\text { Point, on I. NE of West } \\
\text { Lewis I. }\end{array}$ & $\mathrm{DA} 2 / 99 / 35$ & WAM C 28188 (dry) \\
\hline Dampier Archipelago & $\begin{array}{l}2.5 \mathrm{n} . \text { miles WNW of } \\
\text { Marks Point, West } \\
\text { Lewis I. }\end{array}$ & $\mathrm{DA} 2 / 99 / 37$ & WAM C 28187 \\
\hline Dampier Archipelago & $\begin{array}{l}1.65 \mathrm{n} \text {. miles WSW of } \\
\text { Bluff Point, Enderby I. }\end{array}$ & $\mathrm{DA} 2 / 99 / 40$ & WAM C 28186 \\
\hline Dampier Archipelago & $\begin{array}{l}2.4 \text { n. miles SW of SW point } \\
\text { of Goodwyn I. }\end{array}$ & $\mathrm{DA} 2 / 99 / 42$ & WAM C 28185 \\
\hline Dampier Archipelago & $\begin{array}{l}2.4 \text { n. miles WNW of } \\
\text { Rocky Head, Enderby I. }\end{array}$ & $\mathrm{DA} 2 / 99 / 46$ & WAM C 28183 (dry) \\
\hline
\end{tabular}


Dampier Archipelago

Dampier Archipelago

Dampier Archipelago

Dampier Archipelago

Dampier Archipelago

Dampier Archipelago

Dampier Archipelago

Dampier Archipelago

Dampier Archipelago

Dampier Archipelago

Dampier Archipelago

Dampier Archipelago

Dampier Archipelago

Dampier Archipelago

Dampier Archipelago

Dampier Archipelago

Dampier Archipelago

Dampier Archipelago

Dampier Archipelago
3.9 n. miles just $\mathrm{N}$ of $\mathrm{W}$ of

Rocky Head, Enderby I,

3.3 n. miles just $S$ of $W$ of

$W$ point of Eaglehawk I.

6.5 n. miles W of Rocky

Head, Enderby I.

$7.4 \mathrm{n}$. miles $\mathrm{W}$ of $\mathrm{SW}$ point of Goodwyn I.

2.0 n. miles W of Roly Rock DA2/99/56

$1.05 \mathrm{n}$. miles N of Roly Rock DA2/99/57

1.8 n. miles $S$ of Courtenay DA2/99/59 Head Light, Malus I.

Flying Foam Passage, 0.9 n. DA2/99/62 miles NE of $S$ point, Angel I.

$2.4 \mathrm{n}$. miles NW of light on DA2/99/65 East Intercourse I.

$2.75 \mathrm{n}$. miles ESE of Bluff $\quad$ DA2/99/66 Point, Enderby I.

5.5 n. miles SSW of Rocky DA2/99/72 Head, Enderby I.

3.25 n. miles S of Rocky DA2/99/73 Head, Enderby I.

1.95 n. miles SE of Rocky DA2/99/74 Head, Enderby I.

$0.75 \mathrm{n}$. miles $\mathrm{E}$ of $\mathrm{NE}$ point $\mathrm{DA} 2 / 99 / 75$ of Goodwyn I.

0.4 n. miles $W$ of NW point DA2/99/76 of Goodwyn I.

1.2 n. miles $\mathrm{N}$ of $\mathrm{N}$ point $\quad \mathrm{DA} 2 / 99 / 82$ of Kendrew I.

3.15 n. miles ENE of NE DA2/99/83 point of Goodwyn I.

$0.6 \mathrm{n}$. miles SE of King Point, East Lewis I.

1.3 n. miles $W$ of Bluff Point, Enderby I.

DA2/99/96
WAM C 28184

WAM C 28182

WAM C 28181

WAM C 28180 (dry)

WAM C 28179 (dry)

WAM C 28178 (dry)

WAM C 28176

WAM C 28145

WAM C 28144

WAM C 28146

WAM C 28147

WAM C 28148

WAM C 28149

WAM C 28150

WAM C 28151

WAM C 28152

WAM C 28153

WAM C 28154

WAM C 28155

DA3/99/41

DA3 $/ 99 / 55$

WAM C 27434

WAM C 27433

WAM C 25038

WAM C 2165, C 12171

WAM C 12180

WAM C 23751

WAM C 23738

WAM C 21206, C 21208, C 21209

WAM C 21207

WAM C 17798, C 237737, C 21210

WAM C 23739

WAM C 23735
Off Dampier Archipelago

Burrup Peninsula

Mainland
North Rankin "A" Platform

Hearson Cove

Dampier, Hamersley Iron intake pipe

Striatobalanus bimae (Hoek, 1913: 182)

Woodside Collections:

DA1 First Diving Expedition

Dampier Archipelago

3.3 n. miles NNE of

DA2/99/33

WAM C 25924, C 25926

Courtenay Head Light,

Malus I.

Additional Museum Collection Data:

Dampier Archipelago

Enderby I.

Dampier Archipelago

SW of Enderby I. 
$\begin{array}{lll}\text { Dampier Archipelago } & \text { Roly Rocks } & \text { WAM C 21201 } \\ \text { Dampier Archipelago } & \text { West Lewis I., E end } & \text { WAM C 21202 }\end{array}$

Striatobalanus tenuis (Hoek, 1883: 154)

Woodside Collections:

DA1 First Diving Expedition

Burrup Peninsula $\quad 20^{\circ} 31.586^{\prime} S, 116^{\circ} 51.088^{\prime} \mathrm{E} \quad$ DA1/98/30 WAM C 27234

DA2 Dredging Expedition

$\begin{array}{llll}\text { Dampier Archipelago } & \begin{array}{c}5.5 \mathrm{n} \text {. miles N of Lady } \\ \text { Nora I. }\end{array} & \text { DA2/99/24 } & \text { WAM C 28173 to C 28175 } \\ \text { Dampier Archipelago } & \begin{array}{c}3.3 \mathrm{n} \text {. miles NNE of } \\ \text { Coun }\end{array} & \text { DA2/99/33 } & \text { WAM C 25924 }\end{array}$

Courtenay Head Light,

Additional Museum Collection Data:

$\begin{array}{lll}\text { Dampier Archipelago } & \text { Enderby I. } & \text { WAM C 21213, C 21214, } \\ \text { Dampier Archipelago } & \text { Rocky Head, SW Enderby I. } & \text { WAM C 21217 }\end{array}$

Genus Conopea Say, 1822

Conopea calceolus (Ellis, 1758: 853)

Woodside Collections:

DA2 Dredging Expedition

\begin{tabular}{|c|c|c|c|}
\hline Dampier Archipelago & $\begin{array}{l}3.5 \mathrm{n} \text {. miles NE of Cape } \\
\text { Legendre }\end{array}$ & DA2/99/05 & WAM C 28125 \\
\hline Dampier Archipelago & $\begin{array}{l}5.5 \mathrm{n} \text {. miles } \mathrm{N} \text { of } \mathrm{NE} \\
\text { corner of Delambre I. }\end{array}$ & DA2/99/09 & WAM C 28126, C 28127 \\
\hline Dampier Archipelago & $2.25 \mathrm{n}$. miles E of Haüy I. & $\mathrm{DA} 2 / 99 / 13$ & WAM C 28128 \\
\hline Dampier Archipelago & $\begin{array}{l}4.35 \text { n. miles W of Cape } \\
\text { Bruguieres }\end{array}$ & DA2/99/29 & WAM C 28129 (dry) \\
\hline Dampier Archipelago & $\begin{array}{l}3.3 \mathrm{n} \text {. miles NNE of } \\
\text { Courteney Head Light, } \\
\text { Malus I. }\end{array}$ & DA2/99/33(dry) & WAM unregistered \\
\hline Dampier Archipelago & $\begin{array}{l}3.3 \mathrm{n} . \text { miles just } \mathrm{S} \text { of } \mathrm{W} \text { of } \\
\mathrm{W} \text { point of Eaglehawk I. }\end{array}$ & DA2/99/49 & WAM C 28130 \\
\hline Dampier Archipelago & $\begin{array}{l}\text { 1.8 n. miles S of Courteney } \\
\text { Head Light, Malus I. }\end{array}$ & $\mathrm{DA} 2 / 99 / 59$ & WAM C 28131 \\
\hline Dampier Archipelago & $\begin{array}{l}2.4 \mathrm{n} \text {. miles NW of light on } \\
\text { East Intercourse I. }\end{array}$ & $\mathrm{DA} 2 / 99 / 65$ & WAM C 28132 \\
\hline Dampier Archipelago & $\begin{array}{l}1.95 \mathrm{n} \text {. miles SE of Rocky } \\
\text { Head, Enderby I. }\end{array}$ & $\mathrm{DA} 2 / 99 / 74$ & WAM C 28133 \\
\hline Dampier Archipelago & $\begin{array}{l}0.75 \mathrm{n} \text {. miles E of NE point } \\
\text { of Goodwyn I. }\end{array}$ & $\mathrm{DA} 2 / 99 / 75$ & WAM C 28134 \\
\hline Dampier Archipelago & $\begin{array}{l}0.6 \text { n. miles SE of King } \\
\text { Point, East Lewis I. }\end{array}$ & $\mathrm{DA} 2 / 99 / 94$ & WAM C 28135 \\
\hline
\end{tabular}

Conopea sp. 1 cf. navicula (Darwin, 1854: 221)

Woodside Collections:

DA2 Dredging Expedition

$\begin{array}{lll}\text { Dampier Archipelago } & \begin{array}{c}2.4 \mathrm{n} . \text { miles NW of light on } \\ \text { East Intercourse I. }\end{array} & \text { DA2/99/65 WAM C 28139 }\end{array}$

Conopea sp. 2 cf. dentifer (Broch, 1922: 326)

Woodside Collections:

DA2 Dredging Expedition

$\begin{array}{ccc}\text { Dampier Archipelago } & \begin{array}{c}2.4 \mathrm{n} \text {. miles NW of light on } \\ \text { East Intercourse I. }\end{array} & \text { DA2/99/65 WAM C 28140 }\end{array}$ 
Conopea spp

Woodside Collections:

DA1 First Diving Expedition

$\begin{array}{llll}\text { Dampier Archipelago } & \text { Wilcox I. } & \text { DA1/98/17 } & \text { WAM C 27228 } \\ \text { Dampier Archipelago } & \text { Madeleine Shoal } & \text { DA1/98/26 } & \text { WAM C 27227 } \\ \text { Dampier Archipelago } & \text { Legendre I. } & \text { DA1/98/27 } & \text { WAM C 27229 } \\ \text { Dampier Archipelago } & \text { Angel I. } & \text { DA1/98/33 } & \text { WAM C 27230 }\end{array}$

DA2 Dredging Expedition

Dampier Archipelago

Dampier Archipelago

Dampier Archipelago

Dampier Archipelago

Dampier Archipelago

Dampier Archipelago

Dampier Archipelago

Dampier Archipelago
$4 \mathrm{n}$. miles NNW of Cohen I. DA2/99/04 $3.5 \mathrm{n}$. miles NE of Cape Legendre. 2.25 n. miles E of Haüy I. Flying Foam Passage, $0.9 \mathrm{n}$. miles NE of $S$ point of Angel I.

$2.4 \mathrm{n}$. miles NW of light on East Intercourse I.

$3.6 \mathrm{n}$. miles $\mathrm{S}$ of Bluff Point, Enderby I. 1.95 n. mls SE of Rocky Head, Enderby I. $0.75 \mathrm{n}$. miles $\mathrm{E}$ of $\mathrm{NE}$ point of Goodwyn I.

DA2/99/05

DA2/99/13

DA2/99/62

DA2 $/ 99 / 65$

DA2 $/ 99 / 68$

DA2/99/74

DA2/99/75
DA3/99/52

Channel between Enderby I DA3/99/55 and West Lewis I.

Eaglehawk I., N of NW DA3/99/56 Point

NE of North W Reef DA3/99/57

Off Enderby I, SW of DA3/99/65 Rocky Head
WAM C 28136

WAM C 28125

WAM C 28137

WAM C 28138

WAM C 28139, C 28140

WAM C 28141

WAM C 28142

WAM C 28143

WAM C 27388

WAM C 27387

WAM C 27390

WAM C 27389

WAM C 27391

Dampier Archipelago

Dampier Archipelago

Subfamily Acastinae Kolbasov, 1993

Genus Acasta Leach, 1817

Acasta fenestrata Darwin, 1854: 316

Additional Museum Collection Data:

Dampier Archipelago Kendrew I.

WAM C 12182, C 12187

Acasta sulcata Lamarck, 1818: 398

Additional Museum Collection Data:

Dampier Archipelago Kendrew I.

WAM C 12184, C 12186, C 12189

Acasta spp

Woodside Collections:

Burrup Peninsula/Mainland

Burrup Peninsula Watering Cove

WAM C 27306, C 27307

DA1 First Diving Expedition

$\begin{array}{lll}\text { Dampier Archipelago } & \text { Dolphin I. } & \text { DA1/98/01 } \\ \text { Dampier Archipelago } & \text { Legendre I. } & \text { DA1/98/03 } \\ \text { Dampier Archipelago } & \text { Haüy I. } & \text { DA1/98/06 } \\ \text { Dampier Archipelago } & \text { Angel I. } & \text { DA1/98/08 } \\ & & \\ \text { Dampier Archipelago } & \text { Angel I. } & \text { DA1/98/12 } \\ \text { Dampier Archipelago } & \text { Hamersley Shoal } & \text { DAI } 98 / 16 \\ \text { Dampier Archipelago } & \text { Collier Rocks } & \text { DA1/98/20 } \\ \text { Dampier Archipelago } & \text { Delambre I. } & \text { DA1/98/21 }\end{array}$

WAM C 25726, C 25728

WAM C 25300, C 27217

WAM C 25761

WAM C 25732, C 25733, C 25736,

C $27216, C 27222$

WAM C 25741, C 25748

WAM C 27233

WAM C 25755

WAM C 27220 
Dampier Archipelago

Burrup Peninsula

Dampier Archipelago

Dampier Archipelago
Dolphin $I$.

$20^{\circ} 31.586^{\prime} \mathrm{S}, 116^{\circ} 51.088^{\prime} \mathrm{E}$

Legendre I

Angel I.
DA1 $/ 98 / 24$

DA1 $/ 98 / 30$

DA1 $/ 98 / 32$

DA1 $/ 98 / 33$
WAM C 27218

WAM C 25738

WAM C 27219, C 27223

WAM C 27215, C 27221

DA2 Dredging Expedition

\begin{tabular}{|c|c|c|c|}
\hline \\
\hline Dampier Archipelago & $\begin{array}{l}1.9 \text { n. miles } N \text { of NE point } \\
\text { of Delambre I. }\end{array}$ & $\mathrm{DA} 2 / 99 / 10$ & WAM C 28156 \\
\hline Dampier Archipelago & $\begin{array}{l}3.3 \text { n. miles NNE of } \\
\text { Courtenay Head Light, } \\
\text { Malus I. }\end{array}$ & $\mathrm{DA} 2 / 99 / 33$ & WAM C 28157 \\
\hline Dampier Archipelago & $\begin{array}{l}3.3 \text { n. miles NE of } \\
\text { Courtenay Head Light, } \\
\text { Malus I. }\end{array}$ & $\mathrm{DA} 2 / 99 / 34$ & WAM C 28158 \\
\hline Dampier Archipelago & $\begin{array}{l}2.5 \mathrm{n} \text {. miles WNW of Marks } \\
\text { Point, West Lewis I. }\end{array}$ & $\mathrm{DA} 2 / 99 / 37$ & WAM C 28159 \\
\hline Dampier Archipelago & $\begin{array}{l}2.4 \text { n. miles SW of SW point } \\
\text { of Goodwyn I. }\end{array}$ & $\mathrm{DA} 2 / 99 / 42$ & WAM C 28160 \\
\hline Dampier Archipelago & $\begin{array}{l}6.5 \mathrm{n} . \text { miles W of Rocky } \\
\text { Head, Enderby I. }\end{array}$ & $\mathrm{DA} 2 / 99 / 50$ & WAM C 28161 \\
\hline Dampier Archipelago & $\begin{array}{l}2.4 \mathrm{n} \text {. miles NW of light on } \\
\text { East Intercourse I. }\end{array}$ & $\mathrm{DA} 2 / 99 / 65$ & WAM C 28162 \\
\hline Dampier Archipelago & $\begin{array}{l}0.75 \text { n. miles E of NE point } \\
\text { of Goodwyn I. }\end{array}$ & $\mathrm{DA} 2 / 99 / 75$ & WAM C 28163 \\
\hline Dampier Archipelago & $\begin{array}{l}2.9 \text { n. miles E of Tish Point, } \\
\text { Rosemary I. }\end{array}$ & $\mathrm{DA} 2 / 99 / 84$ & WAM C 28164 \\
\hline Dampier Archipelago & $\begin{array}{l}0.7 \mathrm{n} \text {. miles } \mathrm{N} \text { of } \mathrm{W} \text { of } \\
\text { Brigadier } \mathrm{I} \text {. }\end{array}$ & $\mathrm{DA} 2 / 99 / 88$ & WAM C 28165 \\
\hline Dampier Archipelago & $\begin{array}{l}1.05 \text { n. miles WSW of } \\
\text { Rocky Head, Enderby I. }\end{array}$ & $\mathrm{DA} 2 / 99 / 99$ & WAM C 28166 \\
\hline \multicolumn{4}{|c|}{ DA3 Second Diving Expedition } \\
\hline Dampier Archipelago & NW Malus I. & $\mathrm{DA} 3 / 99 / 37$ & WAM C 27409 \\
\hline Dampier Archipelago & S George's Reef & $\mathrm{DA} 3 / 99 / 41$ & WAM C 27406 \\
\hline Dampier Archipelago & $\begin{array}{l}\text { Channel between Enderby } \\
\text { I. and West Lewis I. }\end{array}$ & $\mathrm{DA} 3 / 99 / 55$ & WAM C 27386 \\
\hline Dampier Archipelago & SW East Lewis I. & $\mathrm{DA} 3 / 99 / 63$ & WAM C 27408 \\
\hline Dampier Archipelago & SW Rocky Head & $\mathrm{DA} 3 / 99 / 65$ & WAM C 27407, C 27410 \\
\hline
\end{tabular}

Family Pyrgomatidae Gray, 1825

Subfamily Pyrgomatinae Gray, 1825

Tribe Pyrgomatini Ross and Newman, 1995

Genus Savignium Leach, 1825

Savignium dentatum (Darwin, 1854: 369)

Additional Museum Collection Data:

Dampier Archipelago Kendrew I.

WAM C 16130 (dry), C 16131 (dry)

Pyrgomatid spp

Woodside Collections:

DA1 First Diving Expedition

$\begin{array}{llll}\text { Dampier Archipelago } & \text { Dolphin I. } & \text { DA1/98/01 } & \text { WAM C 25725, C 29425 } \\ \text { Dampier Archipelago } & \text { Legendre I. } & \text { DA1/98/03 } & \text { WAM C 27226 } \\ \text { Dampier Archipelago } & \text { Legendre I. } & \text { DA1/98/04 } & \text { WAM C 25740 } \\ \text { Dampier Archipelago } & \text { Angel I. } & \text { DA1/98/08 } & \text { WAM C 25735 } \\ \text { Dampier Archipelago } & \text { Angel I. } & \text { DA1/98/10 } & \text { WAM C 25757 } \\ \text { Dampier Archipelago } & \text { Hamersley Shoal } & \text { DA1/98/13 } & \text { WAM C 27224 } \\ \text { Dampier Archipelago } & \text { Angel I. } & \text { DA1/98/33 } & \text { WAM C 27225 }\end{array}$

DA2 Dredging Expedition

Dampier Archipelago

2.25 n. miles E of Haüy I.

DA2/99/13

WAM C 28199

Dampier Archipelago

3.3 n. miles NNE of

DA2 $/ 99 / 33$

WAM C 28198 
DA3 Second Diving Expedition

Dampier Archipelago

Dampier Archipelago

Dampier Archipelago

Dampier Archipelago

Dampier Archipelago
NNE Brigadier I.

Brigadier I.

S Goodwyn I.

NE Enderby I.

Angel I.
DA3 $/ 99 / 39$
DA3 $/ 99 / 40$
DA3/99/49
DA3/99/53
DA3/99/55

WAM C 27432

WAM C 29423

WAM C 27430

WAM C 27431

WAM C 25735

Family Balanidae Leach, 1817

Subfamily Balaninae Leach, 1817

Genus Balanus da Costa, 1778

Group of Balanus amphitrite

Balanus amphitrite Darwin, 1854: 240

Woodside Collections:

Burrup Peninsula/Mainland

Burrup Peninsula Withnell Bay

Burrup Peninsula Cowrie Cove

Burrup Peninsula S side Watering Cove

Burrup Peninsula Watering Cove

Burrup Peninsula Rocks N of Watering Cove

Mainland

Mainland

Mainland

Mainland
Dampier Beach

Front Beach, Dampier

Dampier Salt Beach

Point Cleaverville
WAM C 27347 to C 27350, C 27396 , C 29403

WAM C 27353

WAM C 27335

WAM C 27338, C 27344

WAM C 27337

WAM C 27340, C 27341, C 27344, C 27346

WAM C 27352

WAM C 27346

WAM C 27356

WAM C 27211

WAM C 27213, C 27239

WAM C 27402

WAM C 27403

E Enderby I

DA3/99/62

WAM C 25035

WAM C 25034

WAM C 12183

WAM C 23767

WAM C 29402
No other data

Kendrew I.

Hampton Harbour

Hamersley Iron intake pipe, Dampier
Dampier Archipelago

Mainland

Balanus cirratus (Darwin, 1854: 241)

Woodside Collections:

\section{Burrup Peninsula/Mainland}

Burrup Peninsula

Burrup Peninsula

Mainland

Mainland

Mainland

Mainland
Withnell Bay

Watering Cove

Cape Preston

Dampier, Front Beach

Dampier Salt Beach

Point Cleaverville
WAM C 27370, C 27371

WAM C 27359 to C 27366, C 29410

WAM C 27368

WAM C 27367

WAM C 27369

WAM C 27358
WAM C 29416
WAM C 27209
WAM C 27207
Dampier Archipelago
Dolphin I.
DAI $/ 98 / 02$
DAI $/ 98 / 09$
Legendre I.
DA1 $/ 98 / 27$

DA3/99/56

WAM C 27398

Dampier Archipelago NW Eaglehawk I.

Additional Museum Collection Data:

Dampier Archipelago Roly Rocks 
Dampier Archipelago

Burrup Peninsula
Enderby I.

Watering Cove
WAM C 21177

WAM C 27366

Balanus reticulatus Utinomi, 1967: 216

Woodside Collections:

Burrup Peninsula/Mainland

Burrup Peninsula Withnell Bay

Burrup Peninsula Watering Cove

Mainland Cape Preston

Mainland Point Cleaverville
WAM C 27336

WAM C 27339, C 27342, C 27343, C 27351, C 29401

WAM C 27355

WAM C 27354

DA1 First Diving Expedition

$\begin{array}{llll}\text { Dampier Archipelago } & \text { Dolphin I. } & \text { DA1/98/02 } & \text { WAM C 25750 } \\ \text { Dampier Archipelago } & \text { Angel I. } & \text { DA1/98/08 } & \text { WAM C 25734 } \\ \text { Dampier Archipelago } & \text { Angel I. } & \text { DA1/98/09 } & \text { WAM C 27210 } \\ \text { Dampier Archipelago } & \text { Angel I. } & \text { DA1/98/10 } & \text { WAM C 27240 } \\ \text { Dampier Archipelago } & \text { Dolphin I. } & \text { DAI } / 98 / 11 & \text { WAM C 27239 } \\ \text { Dampier Archipelago } & \text { Wilcox I. } & \text { DA1/98/17 } & \text { WAM C 27212 } \\ \text { Dampier Archipelago } & \text { Legendre I. } & \text { DA1/98/27 } & \text { WAM C 27214 } \\ \text { Dampier Archipelago } & \text { Searipple Passage } & \text { DA1/98/31 } & \text { WAM C 27238 }\end{array}$

Balanus sp. nov.

Woodside Collections:

Burrup Peninsula/Mainland

$\begin{array}{ll}\text { Burrup Peninsula } & \text { Withnell Bay. } \\ \text { Burrup Peninsula } & \text { Watering Cove } \\ \text { Burrup Peninsula } & \text { Cowrie Cove } \\ \text { Mainland } & \text { Point Cleaverville }\end{array}$

DA1 First Diving Expedition

$\begin{array}{llll}\text { Dampier Archipelago } & \text { Dolphin I. } & \text { DAI } / 98 / 11 & \text { WAM C 27237 } \\ \text { Dampier Archipelago } & \text { Legendre I. } & \text { DA1 } / 98 / 27 & \text { WAM C 27206 } \\ \text { Dampier Archipelago } & \text { Searipple Passage } & \text { DAI } / 98 / 31 & \text { WAM C 27238, C 29407 }\end{array}$

DA3 Second Diving Expedition

Dampier Archipelago

Dampier Archipelago

Dampier Archipelago
E Enderby I.

Channel between Enderby

I. and West Lewis I.

S Enderby I.

\section{DA3/99/54 \\ DA3/99/55}

$\mathrm{DA} 3 / 99 / 66$
WAM C 27375, C 27376, C 29405

WAM C 27373, C 27379, C 27380

WAM C 27372, C 27377

WAM C 27378

WAM C 27400

WAM C 27401

WAM C 27399

Group of Balanus trigonus

Balanus trigonus Darwin, 1854: 223

Additional Museum Collection Data:

Dampier Archipelago

Dolphin I.

Mainland

Dampier, Hamersley Iron Intake Pipe

WAM C 13900

WAM C 13282, C 17775

Subfamily Megabalaninae Newman, 1979

Genus Megabalanus Hoek, 1913

Megabalanus ajax (Darwin, 1854: 214)

Additional Museum Collection Data:

Dampier Archipelago Kendrew I.

WAM C 29398

Megabalanus cf. ajax (Darwin, 1854: 214)

Woodside Collections:

Burrup Peninsula/Mainland

Burrup Peninsula Watering Cove

WAM C 27334 


\section{Woodside Collections:}

\section{DA1 First Diving Expedition}

$\begin{array}{llll}\text { Dampier Archipelago } & \text { Hamersley Shoal } & \text { DAI/98/16 } & \text { WAM C 27241 } \\ \text { Dampier Archipelago } & \text { Legendre I. } & \text { DA1/98/27 } & \text { WAM C 27205 }\end{array}$

DA3 Second Diving Expedition

Dampier Archipelago Georges Reef DA3/99/42 WAM C 27292

Megabalanus tintinnabulum (Linnaeus, 1758: 668)

Woodside Collections:

DA1 First Diving Expedition

$\begin{array}{llll}\text { Dampier Archipelago } & \text { Legendre I. } & \text { DA1/98/03 } & \text { WAM C 25743 } \\ \text { Dampier Archipelago } & \text { Legendre I. } & \text { DA1/98/04 } & \text { WAM C 25745 } \\ \text { Dampier Archipelago } & \text { Gidley I. } & \text { DAI } / 98 / 07 & \text { WAM C 27204 } \\ \text { Dampier Archipelago } & \text { Unnamed I. } & \text { DAI/98/14 } & \text { WAM C 25721 } \\ \text { Dampier Archipelago } & \text { Wilcox I. } & \text { DA1/98/17 } & \text { WAM C 25747, C 25752 } \\ \text { Dampier Archipelago } & \text { Dolphin I. } & \text { DA1/98/24 } & \text { WAM C 27203 } \\ \text { Dampier Archipelago } & \text { Legendre I. } & \text { DA1/98/27 } & \text { WAM C 27202 }\end{array}$

DA3 Second Diving Expedition

Dampier Archipelago

Dampier Archipelago

NNE Brigadier I.

DA3/99/39

WAM C 27427

Georges Reef

$\mathrm{DA} 3 / 99 / 42$

WAM C 27293

Additional Museum Collection Data:

Dampier Archipelago

Dampier Archipelago

Dampier Archipelago

Dampier Archipelago

Dampier Archipelago

Dampier Archipelago

Dampier Archipelago

Dampier Archipelago

Dampier Archipelago

Dampier Archipelago

Dampier Archipelago Dampier Archipelago

Dampier Archipelago Dampier Archipelago

Dampier Archipelago

Dampier Archipelago

Mainland

Mainland

Mainland

Mainland

Mainland
No other data

ex Panulirus versicolor

Landfall Buoy

Mermaid Sound, sea buoy

Kendrew I.

Kendrew I, W side

Kendrew I., NW side

Kendrew I., Lacepede Buoy 2

Conzinc I.

Roly Rock

Roly Rock ex Panulirus ornatus

Brigadier I.

Goodwyn I

Gidley I.

Enderby I.

Rosemary I.

Dampier

Dampier, Hamersley Iron intake pipe

Karratha

Cape Lambert

Sam's Creek, Roebourne
WAM C 21190, C 25032

WAM C 25032

WAM C 13763

WAM C $15850, C 23800$ to C 23808

WAM C 17767, C 23793, C 23795, C 21185,

C 21188, C 21193, C 29420

WAM C 23794

WAM C 21189

WAM C 14432, C 17769

WAM C 23798

WAM C 20985, C 21186, C 21191, C 21194, C 21195

WAM C 21186

WAM C 20986

WAM C 21183, C 21192

WAM C 25033

WAM C 21196

WAM C 12151

WAM C 17768, C 23792, C 23798

WAM C 16213, C 29415

WAM C 17768

WAM C 21184

WAM C 21178 